\title{
Efficiency and Productivity of the Cement Industry: Pakistani
}

\section{Experience of Deregulation and Privatisation}

\author{
Yaseen Ghulam and Shabbar Jaffry* \\ *Corresponding Author \\ University of Portsmouth, Portsmouth Business School, Economics and Finance Subject Group, \\ Richmond Building, Portland Street, PO1 3DE, UK \\ Email: shabbar.jaffry@port.ac.uk
}

\begin{abstract}
This study evaluates the impact of privatisation on efficiency and productivity of the Pakistani cement industry. To address some of the serious concerns about the problem of dimension and outlier, we use a newly developed unconditional hyperbolic $\alpha$-quantile estimator of Wheelock and Wilson to estimate efficiency (Wheelock D. C., and Wilson P. W., 2008, Non-parametric, unconditional quantile estimation for efficiency analysis with an application to Federal Reserve check processing operations, Journal of Econometrics, 209-225). Subsequently, we use these efficiency estimates to calculate the Malmquist productivity growth and its components. The results show that deregulation and privatisation had the desired positive effect on productivity growth due to technological progress. We conclude that this improvement in the post reform period could be linked to political stability, improved economic conditions and a competitive industry.
\end{abstract}

JEL classification

C14, G21, L32

Keywords

Efficiency; Malmquist productivity; Pakistani cement industry; Reform; Privatisation; Hyperbolic $\alpha$-quantile estimator; Technological progress 


\section{Introduction}

The privatisation wave of 1980s has encouraged research on testing the role of agency problems by comparing the performance of firms pre- and post change of ownership. A number of authors found that performance under private ownership was clearly superior. Others, however, suggested that performance was better under public sector management, or at least that public ownership did not impede efficiency. The two contrasting conclusions led to different policy recommendations in regard to the role of the state and management of public enterprises. There appear to be a number of reasons for this inconsistency. These include; the very short time spans and the small sample size used in these studies, lack of comparable firms and use of inappropriate methodologies.

This study evaluates the impact of deregulation and privatisation on the efficiency and productivity of the Pakistani cement industry. To address the issue of comparability of decision making units (firms), we use a firm-level data set comprising different ownership types such as public, private and privatised, the firms all producing a homogeneous product and operating in a relatively competitive environment ${ }^{1}$. The short time-span sample issue is addressed by collecting and using twenty six years of data (1986 to 2011). Based on available published literature, we argue that our study is the first using two decades of post reform manufacturing firms' data covering four to five business cycles. The results of this study should contribute significantly to the ongoing debate of the effect of reform on efficiency and productivity in developed countries as well as in the developing countries context.

Broadly speaking, studies of the impact of privatisation on the performance of firms have used two methods. First; financial ratios, and secondly; estimation of efficiency and productivity via the production and/or cost function. Studies using the first method include: Megginson et al. [55], Villalonga [88], Harper [44], Boubakri and Cosset [16], Jackson et al. [49], Wei et al. [89],

\footnotetext{
${ }^{1}$ Whilst, there have been allegations of foul play and the formation of cartels since 2000 , investigations by the State run competition commission suggest no such arrangements existed between cement producers.
} 
Boubakri et al. [17], D’Souzaa et al. [32], Boubakri et al. [18], Chen et al. [24], Mathur and Banchuenvijit [52], Farinós et al. [41], Naceur et al. [57], Cook and Uchida [28], Huanga and Yao [46], Huang and Wang [47], and Zhang et al. [97]2. The financial ratios methodology is simple, intuitive and easy to implement but is less preferred amongst some applied researchers. This is due to the non-parametric nature of the technique and being only a partial indicator of performance evaluation.

The estimation of efficiency or productivity on the other hand, is considered a total indicator of performance evaluation ${ }^{3}$. Empirical research on the measurement of efficiency and productivity of a firm is expanding and increasingly becoming popular with governments, policy makers, management gurus and other key stakeholders. Some of the studies that use estimates of efficiency and/or productivity and compare firms performance in pre- and post-reform regimes include: Saal and Parker [68], Rossi [67], Sall and Parker [69,70]), Chirwa [25], Estache et al. [38], Jones and Mygind [50], Resende and Faceanha [64], Cullinane and Song [30], Li and Xu [51], Chirwa [26],Tongzon and Heng [85], Cullinane et al. [31], Brown et al. [21], Okten and Arin [61], Amess and Roberts [5], Sall et al. [71], Al-Obaidan [4] and Asaftei et al. [7]. Despite the fact that the measurement of productivity and efficiency has become common practice, with significant methodological development in the last few years', debate on the appropriate estimator of efficiency and productivity is still inconclusive4.

Two estimators of efficiency measurement are common vis-à-vis parametric stochastic error term regression models based on Stochastic Frontier Analysis (SFA) and mathematical linear

\footnotetext{
2 Some commonly used financial ratios include: return on sales/investment, value of real output, investment as a \% total assets, cash ratios and dividend payout. These ratios are considered as a good starting point, but are insufficient to paint a complete picture as well as having issues with different accounting standards across the globe which makes international comparison difficult.

${ }^{3}$ Composite measure of performance is generally calculated by estimating relationship between input quantities, expenditures, prices and outputs.

${ }^{4}$ See Wheelock and Wilson $(88,89)$ on the shortcoming of different non-parametric estimators.
} 
programming based non-parametric estimator such as Data Envelopment Analysis (DEA). Despite its statistical soundness, the SFA estimator is less straightforward when dealing with multiple outputs alongside assuming a priori functional forms (translog being the most flexible and commonly used ${ }^{5}$ ). In the case of DEA estimator, the common criticisms are first, it could produce unreliable inefficiency estimates due to extreme observations in the data, and second, the estimator suffers from the problem of dimensionality when using a small number of observations and a high number of inputs and outputs, resulting in more sample observations falling on the estimated frontier. In most empirical settings such as ours, the problem of dimensionality is serious issue which increases variance and produces larger confidence intervals. Hence, meaningful estimates would require researchers to use increasing amounts of data as the number of inputs is increased which are a typical feature of banking and manufacturing industries.

Despite criticism, the use of the DEA to estimate efficiency and productivity has been on the rise, and in fact OMEGA's volume 41 was dedicated to the discussion and the use of DEA in various settings. Subsequently, OMEGA alongside the European Journal of Operational Research remained at the forefront of publishing influential studies on the use of the DEA to estimate efficiency. These include Huang et al. [45] studying tourist hotels, Matthews [53] on banking, Hwang et al. [48] on the automobile industry, Rogge et al. [66] on solid waste collection and processing services, Tone and Tsutsui, [84] on US electric utilities, Collier et al. [27] on fisheries, Ray and Ghose [63] on agriculture farms, Doumpos and Cohen [37] on local government, Santos and Amado [72] on judicial systems, and Tüselmann et al. [87] on journal rankings.

\footnotetext{
${ }^{5}$ Authors such as McAllister and McManus, [56]; and Wheelock and Wilson, [90] noted that the translog technology is likely to mis-specify the banks cost relationship. Incorrect specification of the model nonetheless is more of a common feature in most of the empirical studies and thus would lead to less satisfactory root-n consistency.
} 
Since the mid 1990s, there have been a number of developments in the examination of the properties of DEA estimator; for instance Simar and Wilson [76-83], Daraio and Simar [35], Daouia and Simar [34] and Wheelock and Wilson [89,90]. Wheelock and Wilson [89, 90] developed and used an unconditional $\alpha$-quantile hyperbolic estimator to estimate efficiency and productivity. They concluded that their unconditional $\alpha$-quantile hyperbolic estimator is robust, avoids the impact of an outlier, and produces reliable estimates even with fewer observations. Bruffaerts et al. [22] have also confirmed the robustness of the hyperbolic efficiency estimator. We have used this estimator to estimate efficiency and productivity and thus avoid the problem of the dimension and outlier effects typical of this type of study, mentioned above. We also use the other commonly used non-parametric estimators such as DEA, Free Disposal Hull (FDH) and order-m alongside the limitation of each; to facilitate the comparison and to highlight the importance of using an appropriate estimator in estimating efficiency and productivity ${ }^{6}$.

We find, on average, that firms in the post reform period have become less efficient in using their key resources (inputs). Most of this decrease in efficiency is occurred during the 1996 to 2007 period. Efficiency did improve marginally between 2007 to 2011 but not sufficient enough to guarantee an overall improvement in the post reform period. Variations in the efficiency estimates across firms were high before reform was enacted, but relatively low in the post reform period since the late 1990s. The productivity story is equally interesting. Overall, firms experienced a productivity decline in the pre- reform period. This decline was largely due to a technological regress. For the post reform period, we find that firms experienced an improvement in productivity, mainly due to efficiency in the use of technology.

The structure of this paper is such that the next section presents an overview of the Pakistani cement industry as well as a review of the reforms in the early and late 1990s. Section three provides an overview of the empirical literature on the impact of reform on efficiency and productivity. Section four covers the conceptual framework and estimation techniques of

\footnotetext{
${ }^{6}$ See section 3 for survey of literature and contrasting conclusions drawn from different estimators of efficiency.
} 
efficiency and productivity. Data discussion, estimation results, analysis and conclusions are presented in sections five, six and seven respectively.

\section{Developments in the Pakistani cement industry}

Cement manufacturing is a well-established industry in Pakistan, accounting for about $5.5 \%$ of total industrial production, representing 1.4\% of GDP and contributing 30 billion Pakistani Rupees annually to the National Exchequer. Cement manufacturing began in 1921 when Pakistan's first plant was set up with a capacity of 44,500 tonnes per year (tpy). The industry grew steadily until independence in 1947. At this time, two companies with a total of four plants (all in the private sector) were in operation with a total capacity of 480,000 tpy. During the 1950's and 1960's, six more plants were set up, four in the private sector and two in the public sector by the Pakistan Industrial Development Corporation (PIDC). The industry maintained a growth rate of $9.7 \%$ per annum during the 1960s. By the end of 1971, the production capacity of cement had increased to 3.45 million tpy, with $58 \%$ in the public sector and $42 \%$ in the private sector, respectively. A socialist-leaning government nationalised the cement industry in January 1972 and all the cement plants were placed under the Board of Industrial Management (BOIM) and subsequently state run State Cement Corporation of Pakistan (SCCP).

The first clear indication of the reversal of the nationalization policy came with the introduction of Martial Order in 1978 leading to the handing over of three cement manufacturing units to their previous owners7. The pro-industry/market orientated government of Nawaz Sharif sold a total of sixty six manufacturing industrial units and commercial banks to the private sector in 1991-92. Since then, successive governments have been trying to sell public assets such as utilities and infrastructure such as airports, larger nationalized commercial banks and

\footnotetext{
${ }^{7}$ After the government, sympathetic to a social agenda, was removed by the army, and martial-law was imposed in 1977.
} 
development financial institutions but were only able to privatise one power company and a 13.2\% equity stake of Pakistan Telecommunication Ltd (PTCL).

The partial privatisation of cement manufacturing firms started earlier than the mass privatisation programme of 1991-92. SCCP sold part of two state run companies, worth 30 million Rupees, in 1984 to the Investment Corporation of Pakistan (ICP). They later sold these assets on as part of mutual funds to private and institutional investors. In 1992, the government privatised 8 cement companies, 6 to established industrial groups and 2 to an "Employee Groups". The privatisation process of some companies was completed in 1992 but payment and transfer of ownership was delayed due to courts cases and other administrative issues. Two of these privatisations were completed in 1996, and the military regime sold off the remaining two government-owned cement manufacturing units in 1999 and 2003. Since 2003, all the cement manufacturing firms have been operating under private sector ownership. On the eve of privatisation, the government implemented a golden handshake scheme for workers. The response by workers was positive, and some $20-30 \%$ of workers opted for the scheme. The industry is now comprised of two different types of firms namely; privatised and private firms. Private firms are a group of firms which were under private ownership throughout the period. Privatised firms comprised two types. The first type, are those firms that were privatised during mass privatisation of 1991, and the second type are those firms who were subsequently privatised.

The privatisation programme in Pakistan has come under severe criticism partly due to the less than satisfactory performance of some privatised industrial units. This is despite the outstanding performances by other privatised firms. Successive governments have been trying to sell bigger companies such as the public railways and the national airline without success. Since the mid 1990s, immediately after privatisation, other new private cement firms also 
entered the market and some firms of these have gone on to add significant capacities ${ }^{8}$. The number of firms in operation increased which led to increased competition particularly during the period 1995-6 to 2004-5. However, since 2007, the Herfindhal Index has reverted to prereform levels (see Figure 1). This decrease in competition could be explained by the merger of some smaller firms with the larger ones and the expansion of production capacities and total assets.

[Figure 1 about here]

\section{The effect of privatisation and deregulation on efficiency and productivity-review of literature}

The privatisation wave of the 1980s fuelled the ongoing debate of the importance of comparing performance under new management and the evaluation of agency problems. The literature on the question of ownership change and performance has been informative but is not conclusive. For simplification, one could divide the 1980s and 1990s studies into two broader categories. The first is an analysis of the nature of ownerships and performance (private, public and mixed). The second addresses the issue of the firm's performance in pre- and post-privatisation periods.

In the first case, broadly speaking, two sets of conclusions have emerged. Authors such as Bennett and Johnson [13], Boardman and Vining [15], and Boycko et al. [20] found the performance under private ownership clearly superior. Authors such as Aharoni [2], Boardman and Vining [15], Atkinson and Halvorsen [8], and Naqvi and Kemal [58] concluded that performance was superior under the public sector management, or at least public ownership did not present a hurdle to the efficient operation. Early studies that supported the improvement in

\footnotetext{
${ }^{8}$ The industry now employs 150,000 workforces directly or indirectly. Furthermore, industry has started exporting cement to neighbouring countries such as India and Afghanistan as well as Middle East, South Africa and other countries.
} 
the post privatisation period include Bishop and Kay [14], Megginson et al. [55], Bousoffiane et al. [19], Galal et al. [42]9 , Scully [74] and Plane [62].

In the context of the Pakistani privatisation programme of manufacturing firms, there are remarkably, few studies ${ }^{10}$. Notable among them is the study by Aftab and Khan [1] who compared the pre- and post-privatisation record of five firms in three industries, where employees themselves and private firms purchased the units. This study finds that the private sector firms are more successful than the firms purchased by their employees. In general, private ownership results in less labour retrenchment. Naqvi and Kemal [59] concluded "the consequences of privatisation on efficiency, output and the price level have so far been uncertain, and there is enough evidence to suggest that this policy may have lowered the economy's employment potential, worsened the conditions of workers and has led to greater concentration of income and wealth". However, conclusions drawn from these studies could be somewhat misleading because only five years of post privatisation data were used in the study.

Since the turn of the century (2000), significant effort has gone in to evaluating the performance of firms in the pre- and post privatisation periods (for a summary of these findings see Table 1.). Starting with the utility sector, privatisation of telecommunication, water and sewerage, and electricity and gas distribution firms in developed and developing countries has encouraged some authors to examine the effectiveness of change of ownership on efficiency and productivity. Saal and Parker $[68,69]$ concluded that economic efficiency improved post privatisation in the UK. Later on, Sall and Parker $[70,71]$ were unable to show any productivity improvement in the post privatisation period despite significant reductions in labour utilisation. Rossi [67] showed efficiency improvement, but Resende and Faceanha [64] documented no improvement in

\footnotetext{
${ }^{9}$ Galal et al. [42] is the first study that looked into case studies of cost-benefit analysis of privatisation of companies from across the world.

${ }^{10}$ The reason includes the unavailability of data, lack of research culture in the country and slow progress in privatising of remaining public sector firms in the last 15 years.
} 
efficiency in the post privatisation period. $\mathrm{Li}$ and $\mathrm{Xu}$ [51] concluded that privatisation and pressure of competition had a positive effect on labour and total factor productivity.

[Table 1 about here]

Analysing the effect of ownership change in the transportation sector produced some interesting conclusions. Estache et al. [38] documented an improvement in productivity after privatisation. The growth of total factor productivity (TFP) was due primarily to an improvement in output rather than a decrease in input use. Cullinane and Song [30] concluded that privatisation improved container productive efficiency in Korea. Involvement of the private sector had a positive effect on efficiency. Tongzon and Heng [85] using a stochastic frontier model showed private participation improved port operation efficiency and competitiveness. Cullinane et al. [31] rejected the proposition that greater private sector involvement in the container port sector would lead to improved efficiency.

A significant number of studies have also assessed the impact of privatisation and deregulation on manufacturing sector operations. Chirwa [25] concluded the higher technical efficiency of Malawian privatised, state-owned and private ownership companies for the period 1970-97. Saygili and Taymaz [73] using Turkish cement firms observed that privatisation and change of ownership had no effect on technical efficiency. Jones and Mygind [50] documented a positive effect of the change of ownership. Private firms were more efficient and productive as compared to state-owned firms. Chirwa [26] reported high mean technical efficiency in privatised, competing state owned and private companies. Brown et al. [21] documented an immediate and long term positive effect of privatisation on productivity for three countries (Romania, Hungary, and Ukraine), but a negative effect for Russia. Okten and Arin [61] evaluated productive and allocative efficiency of twenty two Turkish privatised cement companies for the period 1983-99. The study concluded that ownership change does in itself promote labour productivity. Amess and Roberts [5] concluded that Polish producer cooperative firms improved their productivity in the first three years of the post privatisation period by a range of 3-20\%. Asaftei et al. [7] 
concluded that ownership change was not sufficient to guarantee a significant improvement in productivity of Romanian manufacturing firms. Privatised firms did not perform any better than public enterprises.

It could be stated that although there exists a vast body of literature on public-private efficiency comparison and the effect of privatisation itself on firms' performance, it is not conclusive. The contribution of this study could be summarised in the following points:

1. By looking at table 1 , a similar study comparable to ours that uses the same nonparametric method to determine the efficiency of a developing country's manufacturing industry after deregulation and privatisation is by Chirwa [25]. The Chirwa study however does not address the fundamental problems of the dimension and poor convergence rate due to its small numbers of observations. We intend to address this by using the partial frontier that is robust to outliers, is consistent, and converge even with a small number of observations.

2. Studies that looked at the manufacturing sector performance and have probably captured a significant number of business cycles include Saygili and Taymaz [73] [sixteen years], Chirwa [26] [twenty years], Bartel and Harrison [11] [fifteen years] and Okten and Arin [61] [seventeen years]. Our study uses twenty years of data on inputs and outputs of the Pakistani cement industry which has evolved over time and has become significant in terms of export earnings (Pakistan now being the world's fifth largest cement exporter) and contributes 30 billion Rupees to the National Exchequer.

3. Most of the studies summarised in table 1 looked at the firm's performance by estimating efficiency or productivity i.e. Chirwa [25] [efficiency], Saygili and Taymaz [73] [efficiency], Chirwa [26] [efficiency], Bartel and Harrison [11] [productivity], Brown et al. [21] [productivity], Okten and Arin [61] [productivity], Amess and Roberts [5] 
[productivity]. A study that evaluated productivity as well as efficiency is by Jones and Mygind [50] but used only five years data and a parametric approach that is subject to criticism due to its dependence on a priori functional form. We intend to address these issues by using more than two and half decades of data and non-parametric methods to assess firms' performance in terms of efficiency as well as productivity.

4. Studies that addressed the issue of privatisation/deregulation and firms' performance since 2000 and summarised in table 1, are limited to either developed countries such as UK, BRICS countries or countries at the advanced stage of their economic development (South Korea, Argentina, Turkey and Indonesia). All these countries have a relatively stable political system, established property rights and a good industrial base. Pakistan being an underdeveloped country, having extremely low per capita income, political instability (government has changed five times since the first phase of the privatisation program) provides an interesting laboratory and hopefully should be a good case study when it comes to the analysis of the impact of change of ownership on a firm's productivity and efficiency.

In the following section, we describe efficiency estimators and show how we used these to estimate efficiency and productivity.

\section{Methodology}

In presenting our methodology to estimate efficiency and productivity we follow Wheelock and Wilson $[89,90]$ to define a family of non-parametric estimators and our notations, conventions, definitions and procedures are similar to their studies. We briefly discuss each estimator alongside its limitations ${ }^{11}$. We first start with familiar and widely used FDH and DEA estimators and then extend our discussion to more recent and advance estimators such as order-m, $\alpha$-quantile and our preferred hyperbolic order- $\alpha$ quantile estimator. In the subsequent analysis, we use cross time

\footnotetext{
${ }^{11}$ For detailed discussion on the development, properties, functionality and limitations of different non-parametric estimators see Wheelock and Wilson [89, 90].
} 
period hyperbolic efficiency estimates to estimate the Malmquist productivity index and its components.

Let us assume firms used input quantities (p) to produce output quantities (q) and standard production possibility set compatible with micro economic theory as $\boldsymbol{p}^{t} \equiv\{(x, y) \mid x$ can produce $y$ at time $t\} \subset \mathbb{R}_{+}^{p+q}$, where input and output vectors are represented by $\mathrm{p}$ input quantities as $x \in \mathbb{R}_{+}^{p} \mathbf{x} \in \mathrm{R}_{+}^{\mathrm{p}}$ and $\mathrm{q}$ output quantities as $y \in \mathbb{R}_{+}^{q}$. This set is representative of a feasible combination of input and output at a given point of time and could vary over time. $\boldsymbol{p}^{t \partial}$ in this framework, could represent an upper boundary of production frontier (benchmark) $\boldsymbol{p}^{t}$. Firms observed performance in terms of input or output compared against this benchmark. The traditional practice is to estimate distance from an arbitrary point $(x, y) \in \mathbb{R}_{+}^{p+q}$ to the boundary $\boldsymbol{p}^{t \partial}$ along a particular direction (minimise inputs use (input orientation/direction) or maximise output (output orientation)). The input and output distance functions of Shephard [75] are defined:

$$
\begin{aligned}
& \theta\left(x, y \mid \boldsymbol{p}^{t}\right) \equiv \sup \left\{\theta>0 \mid\left(\theta^{-1} x, y\right) \in \boldsymbol{p}^{t}\right\} \\
& \lambda\left(x, y \mid \boldsymbol{p}^{t}\right) \equiv \inf \left\{\lambda>0 \mid\left(x, \lambda^{-1}\right) \in \boldsymbol{p}^{t}\right\}
\end{aligned}
$$

The input distance function (1) above measures the distance from $(\mathrm{X}, \mathrm{y})$ to $\boldsymbol{p}^{t \partial}$ in a direction orthogonal to output vector $y$, and output distance function (2) to input vector $x$. Under the constant return to scale (CRS), the output distance function is simply a reciprocal of input distance function $\theta\left(x, y \mid \boldsymbol{p}^{t}\right)=\left(x, y \mid \boldsymbol{p}^{t}\right)^{-1}$. However, the variable returns to scale (VRS) imply that the choice of orientation (input or output) could have serious consequences for efficiency estimates due to the heterogeneity in the size of the firms ${ }^{12}$. Färe $e t$ al. [39] addressed the issue of orientation and measured the distance along a hyperbolic path from a fixed point $(x, y)$ to $\boldsymbol{p}^{t \partial}$ as:

$$
\gamma\left(x, y \mid \boldsymbol{p}^{t}\right) \equiv \sup \left\{\gamma>0 \mid\left(\gamma^{-1} x, \gamma y\right) \in \boldsymbol{p}^{t}\right\}
$$

\footnotetext{
${ }^{12}$ Large size firms are likely to be more efficient compared to small size firms if the output direction is chosen and vice versa.
} 
$\gamma(\mathrm{x}, \mathrm{y} \mid \mathrm{P}) \equiv \sup \left\{\gamma>0 \mid\left(\gamma^{-1} \mathrm{x}, \gamma \mathrm{y}\right)\right\} \in \mathrm{PThe}$ above unknown true distance function of production set $\boldsymbol{p}^{t}$ is estimated from a set $s n=\left\{x_{\mathrm{i}}, y_{i}\right\}_{i=1}^{n}$ of actual input/output combination of sample firms. Later on, at the estimation stage, the unknown true $\boldsymbol{p}^{t}$ is replaced with an estimator of the production set to obtain an estimator of distance function. Deprins et al. [36] proposed a free disposal hull (FDH) of the observations in $\mathcal{S}_{n t}^{t}$ as:

$$
\widetilde{\boldsymbol{p}}\left(\mathcal{S}_{n t}^{t}\right)=\bigcup_{\left(x_{i}, y_{i}\right) \in \mathcal{S}_{n t}^{t}}\left\{(\mathrm{x}, \mathrm{y}) \in \mathbb{R}_{+}^{\mathrm{p}+\mathrm{q}} \mid \mathrm{y} \leq \mathrm{y}_{\mathrm{i}}, \mathrm{x} \geq x_{\mathrm{i}}\right\}
$$

Assuming variable returns to scale (VRS), the DEA estimator is obtained by replacing $\boldsymbol{p}^{\boldsymbol{t}}$ with the convex hull of $\widetilde{\boldsymbol{p}}\left(\boldsymbol{S}_{n t}^{\boldsymbol{t}}\right)$ :

$\widehat{\boldsymbol{p}}_{D E A}^{t}\left(\mathcal{S}_{n t}^{t}\right)=\left\{(\mathrm{x}, \mathrm{y}) \in \mathbb{R}_{+}^{\mathrm{p}+\mathrm{q}} \mid \mathrm{y} \leq \sum_{\mathrm{i}=1}^{\mathrm{n}} \kappa_{\mathrm{i}} \mathrm{y}_{\mathrm{i}}, \mathrm{x} \geq \sum_{\mathrm{i}=1}^{\mathrm{n}} \kappa_{\mathrm{i}} \mathrm{x}_{\mathrm{i}}, \sum_{\mathrm{i}=1}^{\mathrm{n}} \kappa_{\mathrm{i}}=1, \kappa_{\mathrm{i}} \geq 0 \forall_{\mathrm{i}}=1, \ldots, \mathrm{n}\right\}$

DEA and FDH estimates of input or output distance function are obtained by linear programming and numerical methods. So, in a way DEA and FDH estimators are the same with just one difference that the DEA estimator assumes that the production set is convex. The measure defined in $(1,2,3)$ provides a measure of the technical efficiency of sample firms using input output combination at time t. The convex cone $\mathcal{V}\left(\hat{\boldsymbol{p}}_{D E A}^{t}\right)$ is estimated by dropping the constraint $\sum_{i=1}^{n} \kappa_{\mathrm{i}}=1$ in (5) and provides estimates of $\mathcal{V}\left(\boldsymbol{p}^{t}\right)$ and is restricted to only constant returns to scale.

A good deal of progress has been made so far to establish asymptotic properties of the DEA and FDH estimator. However, both estimators suffer from serious problems such as the dimensionality and outlier effect, which make the inefficiency estimates derived from these estimators less reliable. It has been established that due to the problem of dimensionality, the DEA and FDH estimator convergence rates are extremely slow. For example the DEA VRS estimator converges at the rate $\mathrm{n}^{-2 /(p+q+1)}$ and FDH $\mathrm{n}^{-1 /(p+q)}$, where $\mathrm{n}$ is the number of decision making units (DMU). In a case, where firms are producing a single output using four inputs, one would require many more observations compared to firms using a single input to 
produce single output to obtain the convergence of the DEA and FDH estimator and resulting in statistically unreliable inefficiency estimates. Hence, results derived from the estimators such as DEA and FDH are biased downward or upward ${ }^{13}$. Wheelock and Wilson [92] noted that any study with one hundred to two hundred observations and five to ten dimensions is likely to produce statistically less than satisfactory results. Hence, in a nutshell, DEA and FDH estimators could produce statistically misleading efficiency estimates due to outliers, a low convergence rate and an arbitrary choice of input and output orientation. The first and second issues are addressed by use of order- $\alpha$ and order-m estimators. The last issue could be avoided by choosing a hyperbolic distance function.

Recently, to address those issues discussed above, based on the notion of the partial frontier rather than the entire envelope, a new generation of estimators have been developed and used such as "order-m" and "order- $\alpha$ quantile estimator"14.

\section{Order-m estimators ${ }^{15}$}

Cazals et al. [23] developed order-m estimators that do not require the convexity assumption, is root-n consistent and does not suffer due to a high dimension of inputs and output. In addition, being constructed on a partial rather than a full boundary it is not affected by outliers. By

\footnotetext{
${ }^{13}$ The issue of extreme observations could be addressed by using parametric estimator based on the idea of estimating a composite error response function with the error term based on the idea of Aigner et al. [3] and Meeusen and Broeck [54]. Theoretical research has proved that in the case of extreme heterogeneity in the sample, translog functional form can lead to misspecification of the model and produces unreliable efficiency estimates (example of such studies highlighting this issue are Cooper and Mclaren [29], Banks et al. [9], Wheelock and Wilson [90] and Wilson and Carey [95]. Wheelock and Wilson [92] noted that the extension of translog functional form does not guarantee robust estimates.

${ }^{14}$ For details of these estimators see Cazal et al. [23] for "order-m" estimator and Daouia [33], Aragan et al. [6] and Daouia and Simar [34] for conditional "order- $\alpha$ " and unconditional hyperbolic "order- $\alpha$ " quantile and Wheelock and Wilson [93] for hyperbolic order- $\alpha$ quantile estimator.
}

${ }^{15}$ Most of the mathematical notations and formulation for this estimator are taken from Cazal et al. [23]. 
following Wheelock and Wilson [91], we start with the output oriented distance function based on a random draw of $\mathrm{m}$ output vectors subject to given inputs. The random distance function similar to (2) could be written as:

$$
D\left(x, y \mid A_{m}^{t}(x, y)\right) \equiv \inf \left\{\theta>0 \mid(x, y / \theta) \in A_{m}^{t}(x, y)\right\}
$$

Depending upon a random draw of $\mathrm{m}$ output vectors, for any fixed input level say $x_{0}, A_{m}^{t}\left(x_{0}\right)$, is random. For any $\in \mathbb{R}_{+}^{\mathfrak{q}}$, expected maximum output level of order $\mathrm{m}$ for $x$ is defined in such a way that $f_{x}^{t}(x)=f^{t}(x, y) / f^{t}(y \mid x)>0$ and $y_{m}^{t \partial}(x) \equiv y / \mathrm{E}\left[D\left(x, y \mid A_{m}^{t}(x, y)\right)\right]$

The order-m proxy of $\boldsymbol{p}^{t}$ is defined as:

$$
\boldsymbol{p}_{m}^{t} \equiv\left\{(x, y) \mid(x, y) \in \boldsymbol{p}^{t}, y \leq y_{m}^{t \partial}(x)\right\}
$$

Wheelock and Wilson [91] denoted the closure of the complement of $\boldsymbol{p}_{m}^{t}$ as $\boldsymbol{p}_{m}^{t \boldsymbol{\partial}}$ and termed this as an order-m frontier. Under this approach, the observed output quantity of a firm is compared to what could be expected from any $m$ randomly chosen firms that do not use more input quantities than the firm in question. A simple Monte Carlo technique developed by Cazals et al. [23] could be used to estimate maximum feasible output of chosen $m$ random firms, and then the firm's performance could be compared against this benchmark. Similar to an order-m output frontier, the order-m input frontier at input level $x_{0}$ is estimated as:

$$
\boldsymbol{p}_{m}^{\partial}\left(x_{0}\right) \equiv \mathrm{E}\left[\max \left(y_{1}, \ldots, y_{m}\right) \mid x \leq x_{0}\right]
$$

When it comes to choosing the value of $\mathrm{m}$ as trimming parameter, one could choose different values such as five, ten, fifty, hundred or more of representative firms. Due to the small number of firms each year, we choose $\mathrm{m}=5$ in our empirical estimation of order-m output/ input orientation efficiency estimates.

\section{Hyperbolic order-a quantile estimator}

As far as the development of a quantile estimator is concerned, Wheelock and Wilson [92] defined a statistical model with assumptions, such as:

i. Production setP $\boldsymbol{p}^{t}$ is compact and free disposal. 
ii. Sample observations $\mathcal{S}_{n t}^{t}=\left\{\left(x_{\mathrm{i}}, y_{\mathrm{i}}\right)\right\}_{\mathrm{i}=1}^{\mathrm{n}}$ are the realisation of identically independently distributed (iid) random variables with a probability density function $f^{t}(x, y)$ with support over $\boldsymbol{p}^{t}$. Any point $(x, y)$ can be said to be on the frontier ofP, lets say $\boldsymbol{p}^{t \partial}$, if $\left\{\left(\gamma^{-1} x, \gamma y\right)\right\} \notin \boldsymbol{p}^{t}$ for any $\gamma>1$.

iii. It is assumed that at the frontier, the density $f_{\mathrm{t}}$ is strictly positive and sequentially lipschitz continuous.

Following Wheelock and Wilson [93] pp.357, the density function $f^{t}(x, y)$ above implies a probability function:

$$
H^{t}\left(x_{0}, y_{0}\right)=\operatorname{Pr}\left(x \leq x_{0}, y \geq y_{0} \text { at time } t\right)
$$

The above function provides the probability of drawing an observation from $f(x, y)$ that weakly dominates the DMU operating at $\left(x_{0}, y_{0}\right)$. The idea of dominance here implies that firms should be compared in terms of their similarity in the use of input mix and output production. Rather than estimating the efficiency by imposing input or output orientation, a hyperbolic approach maintains a link with the concept of dominance (for details on this, see Wheelock and Wilson [93] pp. 357).

$\left(\mathrm{x}_{0}, \mathrm{y}_{0}\right)$ Now using $H(\cdot, \cdot)$, the hyperbolic distance function can be written as:

$$
\gamma^{t}\left(x, y \mid \boldsymbol{p}^{t}\right)=\sup \left\{\gamma>0 \mid H\left(\gamma^{-1} x, \gamma y\right)>0\right\}(10)
$$

The hyperbolic $\alpha$-quantile distance function can be defined as:

$$
\gamma_{\alpha}^{t}(x, y)=\sup \left\{\gamma>0 \mid H^{t}\left(\gamma^{-1} x, \gamma y\right)>(1-\alpha)\right\}
$$

The hyperbolic $\alpha$-quantile frontier is defined as:

$$
\boldsymbol{p}_{\alpha}^{t \partial}=\left\{\gamma_{\alpha}^{t}(x, y)^{-1} x, \gamma_{\alpha}^{t}(x, y) y \mid(x, y) \in \boldsymbol{p}^{t}\right\}
$$

For an estimation of $\boldsymbol{\gamma}_{\boldsymbol{\alpha}}^{\boldsymbol{t}}(\boldsymbol{x}, \boldsymbol{y})$ and corresponding $\boldsymbol{p}_{\boldsymbol{\alpha}}^{\boldsymbol{t} \boldsymbol{\partial}}$ for the observations in $\boldsymbol{\delta}_{\boldsymbol{n} \boldsymbol{t}}^{\boldsymbol{t}} \mathrm{P}_{\boldsymbol{\alpha}}^{\boldsymbol{\partial}}$, the empirical analogue of equation (9) is defined as: 


$$
\widehat{\mathrm{H}}_{n}\left(x_{0}, y_{0} \mid \mathcal{S}_{\mathrm{nt}}^{\mathrm{t}}\right)=n_{t}^{-1} \sum_{i=1}^{n} \mathrm{I}\left(x_{i} \leq x_{0}, y_{i} \geq y_{0} \mid\left(x_{i}, y_{i}\right) \in \mathcal{S}_{\mathrm{nt}}^{\mathrm{t}}\right)
$$

$\widehat{\mathrm{H}}_{\mathrm{n}}\left(\mathrm{x}_{0}, \mathrm{y}_{0}\right)=\mathrm{n}^{-1} \sum_{\mathrm{i}=1}^{\mathrm{n}} \mathrm{I}\left(\mathrm{x}_{\mathrm{i}} \leq \mathrm{x}_{0}, \mathrm{y}_{\mathrm{i}} \geq \mathrm{y}_{0}\right)$ with $\mathrm{I}(\cdot)$ as an indicator function. Now, the estimator of $\boldsymbol{\gamma}_{\boldsymbol{\alpha}}^{\boldsymbol{t}}(\boldsymbol{x}, \boldsymbol{y})$ is obtained by replacing H(,$\left.;\right)$ with $\widehat{\mathbf{H}}\left(\cdot, \cdot \mid \boldsymbol{S}_{\mathbf{n t}}^{\mathbf{t}}\right)$ to achieve the following:

$$
\hat{\gamma}_{\alpha, n t}^{t}(x, y)=\sup \left\{\gamma>0 \mid \widehat{\mathrm{H}}_{n}\left(\gamma^{-1} x, \gamma y \mid \mathcal{S}_{\mathrm{nt}}^{\mathrm{t}}\right)>(1-\alpha)\right\}
$$

Wheelock and Wilson [92] stated that the computation of $\hat{\gamma}_{\alpha, \mathrm{nt}}^{\mathrm{t}}(\mathrm{x}, \mathrm{y})$ becomes a univariate issue and the estimator of the input/output conditional $\alpha$-quantile distance function can be achieved with small error. Given a point, $\left(\mathrm{x}_{0}, \mathrm{y}_{0}\right)$, one can find initial values $\gamma_{a}, \gamma_{b}$ that would bracket the solution so that $\left(\widehat{\mathrm{H}}_{\mathrm{n}}\left(\gamma_{\mathrm{a}}^{-1} x_{0}, \gamma_{\mathrm{a}} \mathrm{y}_{0} \mid \mathcal{S}_{\mathrm{nt}}^{\mathrm{t}}\right)<(1-\alpha)\right.$ and $\left(\widehat{\mathrm{H}}_{\mathrm{n}}\left(\gamma_{\mathrm{b}}^{-1} x_{0}, \gamma_{\mathrm{b}} \mathrm{y}_{0} \mid \mathcal{S}_{\mathrm{nt}}^{\mathrm{t}}\right)<(1-\alpha)\right.$, then solve for $\hat{\gamma}_{\alpha, n}\left(x_{0}, y_{0}\right)$ using the bisection method. Wheelock and Wilson [93] tested the properties of this estimator and concluded that (1) the estimator is strongly consistent and asymptotically normally distributed and converge at the classical parametric root-n rate. The choice of $\alpha$ in estimating the efficiency estimates using the hyperbolic quantile estimator is an important decision. We experimented with different values but to conserve space we report results only for $\alpha=0.9$ in our empirical section. We use the Wilson [94] FEAR library routines to use a family of non-parametric estimators to estimate efficiency of cement manufacturing firms.

\section{Malmquist Productivity Index}

Similar to Wheelock and Wilson [93], efficiency change over two time periods is calculated by the ratio $\gamma_{\alpha}^{t_{2}}\left(x_{i t 2}, y_{i t 2}\right) / \gamma_{\alpha}^{t_{1}}\left(x_{i t 1}, y_{i t 1}\right)$. A value of less than unity would imply an increase in the technical efficiency in the current period $\left(t_{1}\right)$ compared to the reference period $\left(t_{2}\right)$ relative to $\alpha$ quantiles at time $t_{1}$ and $t_{2}$. An industry level performance measure of efficiency change is computed by the geometric mean of this ratio. For a quantile based measure of efficiency, the change in efficiency between two time periods $\mathrm{t}_{1}$ and $\mathrm{t}_{2}$ is calculated as: 


$$
\varepsilon_{\alpha}\left(t_{1}, t_{2}\right)=\left[\prod_{i \in \mathrm{T}} \frac{\gamma_{\alpha}^{t_{2}}\left(x_{i t 2}, t_{2}\right)}{\gamma_{\alpha}^{t_{1}}\left(x_{i t 1}, y_{i t 1}\right)}\right]^{\frac{1}{\# \mathrm{~T}\left(t_{1}, t_{2}\right)}}
$$

Where $\varepsilon_{\alpha}\left(t_{1}, t_{2}\right)$ are the mean change in efficiency between time periods $\mathrm{t}_{1}$ and $\mathrm{t}_{2}$, relative to the unconditional, hyperbolic $\alpha$-quantile at time $t_{1}$ and $t_{2}$. Whereas $\left(t_{1}, t_{2}\right)$ is the set of firms in existence in both time periods and \# $\mathrm{T}\left(t_{1}, t_{2}\right)$ is the number of firms in the set.

Malmquist productivity index, a dynamic measure of productivity index proposed by Färe et al. [40] between two time periods $t_{1}$ and $t_{2}$ is calculated by first estimating Shephard input, output or hyperbolic path distance functions by using estimators such as DEA, FDH, ORDERM and unconditional hyperbolic $\alpha$-quantile. Malmquist productivity index is defined $\operatorname{as}^{16}$ :

$\mathrm{M}_{\alpha}\left(t_{1}, t_{2}\right)=\left\{\left[\prod_{i \in \mathrm{T}\left(t_{1}, t_{2}\right)} \frac{\gamma\left(\left(x_{i t 2}, y_{i t 2} \mid \mathrm{V}\left(\boldsymbol{p}_{\alpha}^{t_{1}}\right)\right)\right.}{\gamma\left(\left(x_{i t 1}, y_{i t 1} \mid \mathrm{V}\left(\boldsymbol{p}_{\alpha}^{t_{1}}\right)\right)\right.} \times \frac{\gamma\left(\left(x_{i t 2}, y_{i t 2} \mid \mathrm{V}\left(\boldsymbol{p}_{\alpha}^{t_{2}}\right)\right)\right.}{\gamma\left(\left(x_{i t 1}, y_{i t 1} \mid \mathrm{V}\left(\boldsymbol{p}_{\alpha}^{t_{2}}\right)\right)\right.}\right]^{1 / 2}\right\}^{\frac{1}{\# \mathrm{~T}\left(t_{1}, t_{2}\right)}}$

This index measures the mean (geometric) change in the productivity of firms from time $t_{1}$ to $t_{2}$ due to either efficiency change (the first component in equation (16)) or technological progress (the second component in equation (16)). As highlighted by Wheelock and Wilson [93], this measure is similar in term of composition, but differs in two ways to Färe et al. [40]. First, productivity is benchmarked between convex cone boundaries of $\alpha$-quantile and second, hyperbolic direction is used rather than the input or output to avoid issues highlighted in the above discussion. $\mathrm{M}_{\alpha}\left(t_{1}, t_{2}\right)<1$ would indicate a productivity increase and $\mathrm{M}_{\alpha}\left(t_{1}, t_{2}\right)>1$ corresponds to productivity decline.

\section{Data}

We employ a panel data set, for the period 1986 to 2011. This study period represents four to five business cycles and would provide a comprehensive picture of trends and adjustments in

\footnotetext{
${ }^{16}$ For detail see Wheelock and Wilson, [93], pp 361.
} 
input use and production in the pre- and post deregulation/privatisation period. Output and input variables in current prices are deflated by the relevant indices to arrive at a constant price for output and inputs. We approximate the firm's output by total gross sales and real output is worked out by deflating the nominal sales by the cement price index ${ }^{17}$. The inputs used in our study are labour ${ }^{18}$, fixed capital ${ }^{19}$, fuel and energy expenditures ${ }^{20}$ and a residual category of expenditures on raw and packing material ${ }^{21}$. Real values of fixed capital, fuel expenses and raw material are calculated by deflating these accounts by the GDP deflator, fuel price index and raw material price index.

A continuous data series on the number of workers was not available for privatised and private firms for the period 1986 to 1996 . For this purpose, we used information from detailed meetings with the All Pakistan Cement Manufacturer Association, World Bank [96] study, Privatisation Commission of Pakistan, Former Expert Advisory Cell (various publications) and Government of Pakistan [43]. For the privatised firms, a complete set of data was made available while these firms were under public ownership. For the period 1992-6 immediately after these firms were privatised, we were unable to collect information on workforce strength. To fill this gap, we gathered data on the number of workers who opted for a golden handshake at the time of privatisation. Bengali [12], in a study of eight privatised industrial enterprises, including two cement firms, notes that approximately $25 \%$ of the workers who opted for the

\footnotetext{
${ }^{17}$ Our output variable is in values rather than quantity and is similar to Bandyopadhyay [10] and Tsckouras and Skuras [86].

${ }^{18}$ Some authors used total man-days instead of number of workers. We do not have access to this data. Further, due to the law and order situation in Pakistan and strikes. Using total man days proxy would be misleading. Our measure is similar to Riccardi et al [65].

${ }^{19}$ Net fixed capital is used to capture the use of technology. Our measure is similar to Bandyopadhyay [10].

${ }^{20}$ Fuel and energy is an important input and accounts for more than $50 \%$ of the cost of production. We follow Saygili and Taymaz [73] in this regard and include this in our inputs combination.

21 This measure is similar to Saygili and Taymaz [73] and accounts for more than $18 \%$ of cost of production.
} 
golden handshake scheme were retained as contract employees. Detailed interviews with the new management confirmed this conclusion. Hence, for the missing years 1992-6, the number of workers for privatised firm is calculated as a total number of workers at the time of privatisation minus numbers of workers who opted for the golden handshake $+25 \%$ of reinstated workers. For private firms, we have three data points: 1986, 1991 and 1996. The calculation of the remaining years is: 1986 figure $\pm \%$ annual average change during 1986-91 and 1991-6 intervals. Data are available for all firms on this variable from 1997 onward, with some gaps. These gaps were filled by using missing values imputation methods wherever needed. Thus, the series on the numbers of workers calculated in this way is at best an appropriate measure on the workforce strength.

Table 2 shows descriptive statistics of inputs and output in our study. By looking at the table it is apparent that we have a heterogeneous sample of firms. The total number of observations for the whole sample period after excluding a small number of outliers is 407 with an average number of roughly fifteen to sixteen firms per year. In estimating our yearly efficiency estimates, we are likely to encounter the problem of dimension due to a higher number of inputs (four) and an output. We hope to address this by using an unconditional $\alpha$-quantile hyperbolic estimator which is robust, consistent, and deals with the low number of observations better.

[Table 2 about here]

\section{Empirical findings}

First we present estimates of technical efficiency derived through the traditional FDH and DEA estimators (Table 3); using a freely available statistical program "FEAR" written by Wilson $[94]^{22}$. We estimated the efficiency scores for each year of the sample for all firms using that year's production frontier. We present and discuss both input and output oriented

\footnotetext{
22 We are grateful to Professor Wilson for replying to our queries regarding implementation of the hquan routine in the FEAR platform.
} 
estimates and contrast these with hyperbolic estimates for the industry overall, over different time periods ${ }^{23}$. Starting with the FDH estimates of both input and output orientation, efficiency scores are almost identical to unity and as per expectation in both the pre- and post reform period indicating inefficiency to be almost zero with no change in post reform period. Very high efficiency scores could be misleading, and does support the fact that most of the sample firms lie close to the estimated frontier due to the high dimension of inputs space (four in our cases). The DEA estimates show approximately $3 \%$ technical inefficiency in pre- reform years (1986-91) and 6\% in the post reform years (1992-2011), irrespective of input/output orientation, with inefficiency going up on average, from 3\% to $6 \%$ in the post reform period. By subdividing post reform periods, one could suggest that most of this increase in inefficiency has occurred during the immediate period of privatisation (1992-98). The more recent years (2007-11) show some improvement in inefficiency compared to the period 1992-98, but no change compared to the pre- reform period. The DEA hyperbolic estimates almost support this conclusion with the estimates of efficiency marginally different to the DEA input/output orientation estimates (firms experiencing almost $2 \%$ inefficiency in the pre- and post reform period). The change in inefficiency when using DEA estimators could be due to the imposition of the convexity assumption rather than an accurate representation of inefficiency estimates.

[Table 3 about here]

Next, we discuss the efficiency estimates using a partial frontier (order-m) for input and output orientation ${ }^{24}$. In the input orientation case, a value of distance estimate more than unity suggests the firms used more than the expected minimum. Whereas an input distance estimate less than unity indicates that the firms used less than the expected minimum. Looking at Table 3 column

\footnotetext{
${ }^{23}$ We use a geometric mean in our calculation of efficiency scores over different time intervals in both pre- and post reform period.

${ }^{24}$ We present and discuss our order- $\mathrm{m}$ estimates based on trimming parameter $\mathrm{m}=5$. We also experimented with $\mathrm{m}=4$ and present these estimates in Appendix A. Despite the fact that estimates change; broader conclusions regarding trends over time remained the same.
} 
"ORDERMi", technical efficiency did not change in the post reform period. For the output oriented order-m efficiency estimates in column "ORDERMo" a score larger than one indicates that the firms produce more than the expected maximum amount from its observed inputs. A score of less than one means that the firm produces less than its expected maximum. The output oriented order-m efficiency estimates show that efficiency declined in post reform period. This decline is $20 \%$ over the full post reform years and $10 \%$ during the years $2007-2011$. Thus, the decrease in efficiency appears to be higher, compared to the DEA frontier estimates.

The DEA and FDH estimates could be questionable due to the small sample size and slow convergence rates. In the next step, to obtain meaningful estimates, with a root-n convergence rate without imposing the convexity assumption with the DEA, we used an unconditional $\alpha$ quantile estimator and reached some interesting conclusions. The input oriented technical efficiency estimates indicate roughly a 10\% reduction in technical efficiency in the post reform period. This decline is approximately $3 \%$ for the period 1992-8. The output oriented technical efficiency estimates improved in the post reform period. This increase is $2.5 \%, 4 \%$ and $11.6 \%$ during 1992 to 2011,1999 to 2011 and 2007 to 2011 retrospectively ${ }^{25}$. Our preferred hyperbolic estimator reveals a more interesting story. We estimate that, on average in the pre-reform period, firms used just $57 \%$ of the input quantity and produced 1.8 times output $(1 / 0.5685)$ than a firm (perhaps hypothetical) located on $\alpha=0.9$ quantile frontier along a hyperbolic path. In the post reform period, firms used $71 \%$ of the input and produced $1 / 0.71=1.4$ times more output than a firm located on $\alpha=0.9$ quantile frontier along a hyperbolic path. Hence, based on these estimates, we conclude that firms on average became less efficient in the post reform period ${ }^{26}$.

\footnotetext{
25 These contradictory results indicate the importance of the choice of orientation in estimating efficiency of firms. In most of the studies we reviewed, the authors made arbitrary decisions in regard to the choice of orientation and subsequently tried to justify their choice with some success. Hence, it proves the point that it would be preferable to choose the hyperbolic estimator to avoid bias at the estimation stage.

${ }^{26}$ Our above discussion is based on $\alpha$ value equal to 0.9 . We also experimented with $\alpha$ value of $0.8,0.85$, and 0.87 . These estimates are presented in Appendix A. Estimates do change due to the relatively small population of our cement firms; but broader conclusions of the impact of reform are almost same.
} 
Figure 2 displays the industry trend of unconditional hyperbolic $\alpha$-quantile efficiency estimates alongside the variance. We present the average, median and geometric mean of efficiency estimates. By looking at the figure, the geometric mean shows that during 1986-95, efficiency was stagnant, then from 1996 onwards until 2007, efficiency decreased contrary to expectations. Efficiency did improve marginally during 2007 to 2011, but not sufficient enough to guarantee an overall improvement in the post reform period. Qualitatively, the average efficiency trends report the same story irrespective of the method. Variations in efficiency estimates measured by the variance of the hyperbolic graph efficiency estimates, could give an indication of firms working to achieve uniformity in operations. Variations across the firms were relatively high before reform and in the initial years of the post reform period but remained relatively low in the post reform period from 1997 onward.

[Figure 2 about here]

The industry trends of technical efficiency tell a fascinating story, but are unable to provide an indication of what happened to firms belonging to different ownership categories (public, private and privatised). Next, we stratified firms as per their ownerships and then calculated the geometric means of efficiency scores for each time period. The results of this exercise are depicted in Figure 3. The first group consists of those firms privatised in 1991-2 and are labelled 'privatised'. We follow these firms in both periods (pre- and post privatisation). The next category consists of those firms who were in the private sector in pre- privatisation years and remained so in the post reform period (labelled as 'private'). The third category (labelled 'public') consists of those firms who were pure public sector firms (government owned) until they were privatised either in 1991-92 or subsequently afterwards.

Figure 3 reveals that firms that were privatised in 1992 did not show any change in efficiency in the pre- reform period except in 1986. When it comes to the post reform period, technical efficiency declined during the period 1993 to 2007, but since 2007, these firms show a slight improvement in efficiency. Nonetheless, these firms witnessed an overall reduction of $8-9 \%$ in 
their technical efficiency between 1992 and 2011. Private sector firms did experience some improvement in efficiency immediately after the reform. During the period 1996 to 2002, these firms did not do so well and faced a significant reduction in efficiency, but their efficiency has been flat since. Overall, these firms experienced a $4 \%$ decrease in efficiency in the post reform period. Public sector firms saw a positive response in the immediate post reform period. But since 1995, the firms' performance has remained stable and experienced no change in efficiency.

[Figure 3 about here]

Table 4 presents the geometric means of Malmquist productivity estimates alongside its components ${ }^{27}$. We present estimates for the overall industry and by ownerships. Mean values of less than 1 indicates an increase in productivity and greater than 1 indicates a decrease in productivity. Looking at the trend, firms experienced a productivity decline $(2 \%)$ in the prereform period with the exception of 1988. During the post reform period, firms experienced a decline during only 4 years of the 20 year period, whereas, overall, $2.1 \%$ per annum growth in productivity was achieved by the industry in the post reform period (1992-2011). The year 2007 seems to be an exceptional year whereby productivity declined by $14.6 \%$, due to the political uncertainty and elections within Pakistan. If we exclude 2007 from the post reform period, then the gains in productivity are higher (annual 2.9\% during 1992-2011 and 4.4\% growth per annum during 1999 to 2011).

Next, we examine the sources of productivity improvement/decline by efficiency and technology change (movement in $\alpha$-quantile frontier). First, by looking at the pre-reform period, we get the impression that the decline in productivity in the pre- reform period was not largely due to a

\footnotetext{
${ }^{27}$ We present and discuss our main productivity estimates and its components using a hyperbolic quantile estimator discussed in the methodology section with $\alpha=0.9$. Due to the arbitrary choice of $\alpha$ and our respected reviewers' suggestion, we also experimented with $\alpha=0.8$. These estimates are provided in Appendix B. As expected, due to fewer firms in each years' sample, there are some changes in the estimates, but broader conclusions in term of trends and the impact of reforms (positive/negative) remained the same.
} 
decrease in efficiency but to technological regress ${ }^{28}$ (out of a total $2 \%$ decline, $0.6 \%$ was contributed by a decrease in efficiency and $1.4 \%$ by a change in technology). We also calculated these estimates by ownerships. For firms that were privatised in 1991-2, a reduction of $3.5 \%$ in productivity was entirely due to a negative contribution of efficiency change. Technology actually improved, albeit marginally, for these firms during this time period. Results for technological improvement for this group of firms are not surprising, given the fact that majority of these firms were relatively new with modern technology (dry process of production). Firms already in the private sector experienced nearly a 10\% decline in productivity and both sources contributed equally (efficiency change $-3.5 \%$ and technology $-6.1 \%$ ). This is interesting as 4 private firms operating during this period were relatively new and small sized compared to firms in the public sector. Public sector firms, not privatised in the initial phase and privatised subsequently in late 1990s and early 2000s, on the other hand, did not experience any change in productivity during 1986-91.

\section{[Table 4 about here]}

For the post reform period, we observe, that industry experienced an improvement in productivity due to the improvements in technology (out of a total $2.1 \%$ increase, $1.6 \%$ was the contribution by change in technology and $0.5 \%$ in efficiency ${ }^{29}$. For privatised firms, a $1.6 \%$ increase in productivity ${ }^{30}$ was due to a nominal positive contribution of efficiency $(0.6 \%)$ and

\footnotetext{
${ }^{28}$ Our results of pre- privatisation productivity decline are consistent with Amess and Roberts [5] who estimated a $1 \%$ productivity decline of Polish producer cooperatives.

${ }^{29}$ Improvement in technology is similar to Saal $e t$ al. [71]) who estimated a productivity decline post privatisation due to the efficiency decline despite technological improvements. Very low and insignificant contribution of efficiency improvement is similar to Rossi [67], Resende and Facanha [64] and Saygili and Taymaz [73] in assessing the impact of privatisation on the gas distribution in Argentina, telecommunication in Brazil and cement industry in Turkey. In all these studies the authors were unable to find the evidence that privatisation improves efficiency.

${ }^{30}$ Gains in productivity in post privatisation are similar to Estache et al. [38]. Improvement in productivity, in the post privatisation period, is also similar to Cullinane and Song [29] study of South Korean port terminal privatisation. Increases in productivity, post privatisation, is encouraging but contrary to Saal and Parker [70] who estimated a decline in productivity in the England and Wales water and sewerage provision by using quality adjusted TFP during
} 
change in technology $(2.2 \%)^{31}$. The results for the technological improvements are not surprising given the fact that these firms were relatively new in the pre-reform period, but had enough experience between 1992 and 2011. Firms already in the private sector experienced nearly a 1.4\% increase in productivity, and both sources contributed equally (efficiency change $0.7 \%$ and technology $0.7 \%$ ). This finding is interesting, given the fact that a significant number of new firms entered this category in mid 1990s and early 2000s as well as the mergers and acquisition of smaller firms with larger ones during this period. Public sector firms that were privatised subsequently in the late 1990s and early 2000s, on the other hand, recorded an impressive $7.5 \%$ growth in productivity per annum, as a result of technological improvement $(5.1 \%)$ and efficiency improvement of $2.5 \%$. This impressive performance should be treated cautiously, however, because there were only three firms this group.

To further observe the initial impact of privatisation, we sub-divided the post privatisation period into two sub-periods: 1992-8 covering the initial impact and the more recent period of 1999 to 2011. Overall, the industry as a whole and firms operating in the private sector did not experienced any significant growth in the initial years of the post privatisation period (see Table 4). Firms privatised in 1991, however, experienced a productivity decline of $4 \%$ per annum during 1992-8 and a decline in efficiency was the main contributing factor. This initial negative impact of privatisation on productivity is similar to Brown et al. [21] estimates of the Russian manufacturing industry.

Next we estimated Pearson's correlation coefficient between productivity growth and a host of demand factors such as macroeconomic conditions, public finances (government being a large

the post privatisation period. They concluded that the decline in productivity could have been due to significant capital investment in the post privatisation period to meet new tighter regulatory requirements. Privatised firms in our sample also made significant capital investment to upgrade technology of production and to add capacities. Hence, post privatisation better performance is even more commendable. Post privatisation productivity improvement is consistent with Amess and Roberts [5]) growth of 3-20\% per annum.

31 Our rate of growth in technology is similar to Saal et al. [71]. 
consumer of cement in the construction of roads, buildings, army cantonments, and infrastructure), business environment, external sector and firm/industry conditions. The results of this exercise are presented in Table 5. A negative coefficient would indicate a positive relationship between productivity (malm) and the relevant variable. This means that a value of productivity index of less than one and/or a negative value would indicate a positive change (growth) in productivity.

[Table 5 about here]

Starting with firms and industry specific variables, we observe a negative correlation coefficient between firm age (old), exporter (volume of export) and a positive sign for industry competition (measured with the Herfindhal Index). Hence, older firms are more productive and an increase in exports as well as competition (less value of hhi_grsa) promotes productivity ${ }^{32}$. The macro economy (volume of GDP (gdp)) and manufacturing growth (manufac)) enhances productivity ${ }^{33}$. The same is true for investment (measured by gross fixed capital formation (gfcf), public investment (pubinv), and investment in government development projects (devexp)). An increase in population (pop) creates more demand for housing and infrastructure and hence enhances productivity.

\footnotetext{
${ }^{32} \mathrm{~A}$ high value of $\mathrm{HHI}$ would indicate that the market is being monopolised by a few firms and therefore there is less incentive for existing firms to operate efficiently. Hence, a higher value of HHI would lead to a reduction in productivity. Nickell [60] suggested that based on theoretical underpinning, an increase in competition would lead to an increase in productivity due to better corporate governance. Asaftei et al. [7] investigating the role of competition concluded that privatised firms operating in competitive industries experienced significant growth in the post privatisation period as compared to those firms working in a less competitive environment. Hence, institutional change rather than change of ownership would encourage firms to become efficient and productive. Our positive relation of productivity and exports sales are similar to Saygili and Taymaz [73]. Chirwa [25] also concluded that HHI is negatively correlated with efficiency.

${ }^{33}$ Our positive relation of productivity improvement and economic growth is similar to Saygili and Taymaz [73].
} 
The external sector performance in terms of the exchange rate (exchr) and foreign remittances (remit) also contributes to productivity. Depreciation of the Pakistani Rupee (Pak. Rs.) encourages exports and productivity, whilst rising remittances generate more demand for cement. A negative coefficient for our main interest variable (dummy variable equal to one for period 1992 onward) indicates that productivity has been rising since 1992 compared to the preprivatisation period. Political stability (politics) measured through the number of years since a government was in power is correlated negatively with productivity indicating political stability promotes productivity.

\section{Conclusion}

The estimation of efficiency of firms has been a growing area of research to examine the effect of deregulation and privatisation since the late 1980s and mid 1990s. The fast convergence and flexibility to carry out statistical inferences has made a parametric estimator such as the stochastic frontier immensely popular amongst researchers. However, the a priori assumption of functional form makes the estimator somewhat less satisfactory. The DEA based non-parametric estimator is able to address some of the issues inherent in the parametric estimator. Frequent use of this estimator is mainly due to its flexibility and the fact that the estimator follows the logic of "data speaks for itself'. This flexibility is, arguably, an inherent flaw. Recently, theoretical studies have shown that the convexity property of the DEA estimator and small sample issues make this estimator less robust. This casts serious doubts on the conclusions drawn from studies on the impact of deregulation and privatization that used the non-parametric DEA frontier.

New estimators based on the idea of a partial frontier such as order-m and conditional $\alpha$-quantile that address the issue of the convex envelope and are robust to outlier and dimension issues (such as in our case) have recently been developed. This study uses recently developed robust non-parametric unconditional $\alpha$-quantile estimator of Wheelock and Wilson [89, 90] to estimate the level of technical efficiency and productivity in the Pakistani cement industry. This study covers at least four-five business cycles and the tenure of various governments. The estimates of 
the efficiency and productivity in this paper are robust in respect to outliers and the problem of dimension. One of the limitations of our study is that the number of observations for each year and the population of firms is comparatively low. Hence our estimates of efficiency and productivity may be less precise but nonetheless, these estimates shed light on the effect of deregulation/privatisation on efficiency and productivity.

We conclude that the Pakistani cement industry had experienced improvements in productivity in the post reform period across all its ownerships categories. However, we are unable to say the same for efficiency improvements. The improvement in productivity was achieved due to technological growth. The productivity improvement during 1999 to 2007 was more pronounced due to an enhanced macroeconomic environment, which leads us to conclude that rather than just a change of ownership, the enabling environment is extremely important. We also identified a greater degree of heterogeneity in the efficiency levels across three ownership categories that persisted throughout the sample period. 


\section{References}

[1] Aftab S. Khan SR. Comparative privatisation experience in Pakistan: employee vs private ownership. Islamabad Pakistan: Sustainable Development Policy Institute (SDPI); 1995.

[2] Aharoni Y. The evaluation and management of state owned enterprises. Cambridge, Mass.: Ballinger; 1986.

[3] Aigner DJ., Lovell CAK., Schmidt P. Formulation and estimation of stochastic frontier production function models. Journal of Econometrics 1977; 6(1): 21-37.

[4] Al-Obaidan AM. Efficiency effect of privatization in the developing countries. Applied Economics 2002; 34(1): 111-117.

[5] Amess K., Roberts BM. The productivity effects of privatization. International Review of Financial Analysis 2007; 16(4): 354-366.

[6] Aragon Y., Daouia A., Thomas-Agnan C. Nonparametric frontier estimation: a conditional quantile-based approach. Econometric Theory 2005; 21(2): 358-389.

[7] Asaftei G., Kumbhakar SC., Mantescu D. Ownership, business environment and productivity change. Journal of Comparative Economics 2008; 36(3): 498-509.

[8] Atkinson SE., Halvorsen R. Parametric efficiency tests, economies of scale, and input demand in U.S. electric power generation. International Economic Review 1984; 25(3): 647-662.

[9] Banks J., Blundell, R., Lewbel A. Quadratic Engel curves and consumer demand. Review of Economics and Statistics 1997; 79(4): 527-539.

[10] Bandyopadhyay S. In search of contextual variables in a stochastic DEA framework: effect of regulation on efficiency of Indian cement industry. Journal of the Operational Research Society 2011; 62(9): 1621-1637.

[11] Bartel AP., Harrison AE. Ownership versus environment: disentangling the sources of public-sector inefficiency. Review of Economics and Statistics 2005; 87(1): 135-147.

[12] Bengali K. Social dimensions of privatisation in Pakistan. International Labour Organization (ILO), Geneva, Switzerland; 1998.

[13] Bennet T., Johnson MH. Public vs. private provision of collective goods and services: garbage collection revisited. Public Choice 1979; 34(1): 55-64. 
[14] Bishop MR., Kay JA. Privatisation in the United Kingdom: lessons from experience. World Development 1989; 17(5): 643-657.

[15] Boardman AE., Vining AR. Ownership and performance in competitive environment: a comparison of the performance of private, mixed and public enterprises. Journal of Law and Economics 1989; 32(1): 1-33.

[16] Boubakri, N., Cosset JC. Does privatization meet the expectations in developing countries? A survey and some evidence from Africa. Journal of African Economies 2002; 11(sup. 1): 111140.

[17] Boubakri N., Cosset JC., Guedhami O. Privatization, corporate governance and economic environment: firm-level evidence. Asia Pacific-Basin Finance Journal 2004; 12(1): 65-90.

[18] Boubakri, N., Cosset, JC., Guedhami O. Post privatization corporate governance: the role of ownership structure and investor protection. Journal of Financial Economics 2005; 76(2): 369399.

[19] Boussofiane A, Martin S., Parker D. The impact on technical efficiency of the UK privatization programme. Applied Economics 1997; 29(3): 297-310.

[20] Boycko M., Shleifer A., Vishny RW., A theory of privatisation. Working Paper. Harvard University; 1993.

[21] Brown JD., Earle JS., Telegdy A. The productivity effects of privatization: longitudinal estimates from Hungary, Romania, Russia, and Ukraine. Journal of Political Economy 2006; 114(1): 61-99.

[22] Bruffaerts, C., De Rock, B., Dehon, C. The robustness of the hyperbolic efficiency estimator. Computational Statistics and Data Analysis 2013; 57(1): 349-363.

[23] Cazals C., Florens JP., Simar L. Nonparametric frontier estimation: a robust approach. Journal of Econometrics 2002; 106(1): 1-25.

[24] Chen G., Firth M., Rui O. Have China's enterprise reforms led to improved efficiency and profitability for privatised SOEs? Emerging Markets Review 2006; 7 82-109.

[25] Chirwa EW. Privatization and technical efficiency: evidence from the manufacturing sector in Malawi. African Development Review 2001; 13(2): 276-307. 
[26] Chirwa EW. Industry and firm effects of privatization in Malawian oligopolistic manufacturing. The Journal of Industrial Economics 2004; 52(2): 277-289.

[27] Collier, TC., Mamula, A., Ruggiero, J. Estimation of multi-output production functions in commercial fisheries. Omega 2014; 421, 157-165.

[28] Cook P., Uchida Y. The performance of privatised enterprises in developing countries. Journal of Development Studies 2008; 44(9): 1342-1353.

[29] Cooper RJ., McLaren KR. A system of demand equations satisfying effectively global regularity conditions. The Review of Economics and Statistics 1996; 78(2): 359-64.

[30] Cullinane K., Song DW. A stochastic frontier model of the productive efficiency of Korean container terminals. Applied Economics 2003; 35(3): 251-267.

[31] Cullinane K., Ji P., Wang T. The relationship between privatization and DEA estimates of efficiency in the container port industry. Journal of Economics and Business 2005; 57(5): 433 462.

[32] D’Souzaa J., Megginson W., Robert N. Effect of institutional and firm-specific characteristics on post-privatization performance: Evidence from developed countries. Journal of Corporate Finance 2005; 11(5): 747-766.

[33] Daouia A. Nonparametric analysis of frontier production functions and efficiency measurement using nonstandard conditional quantiles. Ph.D. Dissertation.Groupe de Recherche en Economie Mathématique et Quantititative, Université des Sciences Sociales, Toulouse I, et Laboratoire de Statistique et Probabilités, Université Paul Sabatier Toulouse III; 2003.

[34] Daouia A., Simar L. Nonparametric efficiency analysis: a multivariate conditional quantile approach. Journal of Econometrics 2007; 140(2): 375-400.

[35] Daraio C., Simar L. Introducing environmental variables in nonparametric frontier models: a probabilistic approach. Journal of Productivity Analysis 2005; 24(1): 93-121.

[36] Deprins D., Simar L., Tulkens H. Measuring labor inefficiency in post offices. in the performance of public enterprises: concepts and measurements, eds.M. Marchand, P. Pestieau, and H. Tulkens, Amsterdam: North-Holland; 1984: 243-267. 
[37] Doumpos, M., Cohen, S. Applying data envelopment analysis on accounting data to assess and optimize the efficiency of Greek local governments. Omega 2014; 46, 74-85.

[38] Estache A., Marianela G., Lourdes T. What does privatization do for efficiency? Evidence from Argentina's and Brazil's railways. World Development 2002; 30(11): 1885-1897.

[39] Färe R., Grosskopf S., Lovell CAK. The measurement of efficiency of production. Boston: Kluwer-Nijhoff Publishing; 1985.

[40] Färe, R., Grosskopf, S., Lindgren, B., and Roos, P. Productivity developments in Swedish hospitals: a Malmquist output approach," in Data Envelopment Analysis: theory, methodology and applications, eds. A. Charnes, W. W. Cooper, A. Y. Lewin, and L. M. Seiford, Dordrecht: Kluwer Academic 1994.

[41] Farinós JE., García CJ., Ibáñez AM. Operating and stock market performance of stateowned enterprise privatizations: the Spanish experience. International Review of Financial Analysis 2007; 16(4): 367-389.

[42] Galal A, Jones LP., Tandon P., Vogalsang I. Welfare consequences of selling public enterprises. Washington D.C.: The World Bank; 1994.

[43] Government of Pakistan, National Development Finance Corporation (NDFC). Cement directory. Karachi, Pakistan; 1991.

[44] Harper, J. Short-term effects of privatization on performance in the Czech Republic. Journal of Financial Research 2001; 24 (1): 119-31.

[45] Huang, C W., Ho, FN., Chiu, YH. Measurement of tourist hotels' productive efficiency, occupancy, and catering service effectiveness using a modified two-stage DEA model in Taiwan. Omega 2014; 48, 49-59.

[46] Huang LW., Yao Y. Impacts of privatization on employment: evidence from China. Journal of Chinese Economics and Business Studies 2010; 8(2): 133-156.

[47] Huang Z., Wang K. Ultimate privatization and change in firm performance: evidence from China. China Economic Review 2011; 22(1): 121-132. 
[48] Hwang, SN., Chen, C., Chen, Y., Lee, HS., Shen, PD. Sustainable design performance evaluation with applications in the automobile industry: Focusing on inefficiency by undesirable factors. Omega 2013; 413, 553-558.

[49] Jackson J., Loh A., Kam B. Sri Lanka's plantation sector: a before-and-after privatization comparison. Journal of International Development 2003; 15(6): 727-745.

[50] Jones DC., Mygind N. Ownership and productive efficiency: evidence from Estonia. Review of Development Economics 2002; 6(2): 284-301.

[51] Li W., Xu LC. The impact of privatization and competition in the telecommunications sector around the world. Journal of Law and Economics 2004; 47(2): 395-430.

[52] Mathur I., Banchuenvijit W. The effects of privatization on the performance of newly privatized firms in emerging markets. Emerging Markets Review 2007; 8(2): 134-146.

[53] Matthews, K. Risk management and managerial efficiency in Chinese banks: A network DEA framework. Omega 2013; 412, 207-215.

[54] Meeusen W, Broeck J. Efficiency estimation from Cobb-Douglas production functions with composed error. International Economic Review 1977; 18 (2): 435-444.

[55] Megginson WL., Nash RC, Rasdenburgh Van M. The financial and operational performance of newly privatised firms: an international empirical analysis. The Journal of Finance 1994; XLIX (2): 403-452.

[56] McAllister, PH., McManus D. Resolving the scale efficiency puzzle in banking. Journal of Banking and Finance 1993; 17(2-3): 389-405.

[57] Naceur S., Ghazouani S., Omran M. The performance of newly privatized firms in selected MENA countries: The role of ownership structure, governance and liberalization policies. International Review of Financial Analysis 2007; 16(4): 332-353.

[58] Naqvi NH, Kemal AR. The privatisation of the public enterprises in Pakistan. The Pakistan Development Review 1991; 30(2): 105-144.

[59] Naqvi NH, Kemal AR. Privatisation efficiency and employment in Pakistan. In "How does privatisation work? Essays on privatisation in honour of Professor V.V. Ramanadham”. London: Routledge; 1997. 
[60] Nickell SJ. Competition and corporate performance. Journal of political economy 1996; 104(4): 724-746.

[61] Okten C., Arin KP. The effects of privatization on efficiency: how does privatization work? World Development 2006; 34(9): 1537-1556.

[62] Plane P. Privatization, technical efficiency and welfare consequences: the case of the Cote d'Ivoire Electricity Company (CIE). World Development 1999; 27(2): 343-360.

[63] Ray, S. C., Ghose, A. Production efficiency in Indian agriculture: An assessment of the post green revolution years. Omega 2014; 44, 58-69.

[64] Resende M., Facanha L., Privatization and efficiency in Brazilian telecommunications: an empirical study. Applied Economics Letters 2002; 9(12): 823-826.

[65] Riccardi R., Oggioni G., Toninelli R. Efficiency analysis of world cement industry in presence of undesirable output: application of data envelopment analysis and directional distance function. Energy Policy 2012; 44: 140-152.

[66] Rogge, N., De Jaeger, S. Measuring and explaining the cost efficiency of municipal solid waste collection and processing services. Omega 2013; 414, 653-664.

[67] Rossi MA. Technical change and efficiency measures: the post-privatisation in the gas distribution sector in Argentina. Energy Economics 2001; 23(3): 295-304.

[68] Saal DS., Parker D., The impact of privatisation and regulation on the water and sewerage industry in England and Wales: a translog cost function approach. Managerial and Decision Economics 2000a; 21(6): 253-268.

[69] Saal DS., Parker D. Productivity \& Price Performance in the Privatised Water \& Sewerage Companies of England \& Wales. Research paper series /Aston Business School Research Institute 2000b; 29: 38.

[70] Saal DS., Parker D., Productivity and price performance in the privatized water and sewerage companies of England and Wales. Journal of Regulatory Economics 2001; 20(1): 61-90.

[71] Saal DS., Parker D., Weyman-Jones T., Determining the contribution of technical change, efficiency change and scale change to productivity growth in the privatized English and Welsh water and sewerage industry: 1985-2000. Journal of Productivity Analysis 2007; 28(1): 127-139. 
[72] Santos, SP., Amado, CA. On the need for reform of the Portuguese judicial system-Does Data Envelopment Analysis assessment support it? Omega 2014; 47, 1-16.

[73] Saygili S., Taymaz E. Privatization, ownership and technical efficiency a study of the Turkish cement industry. Annals of Public and Cooperative Economics 2001; 72(4): 581-605.

[74] Scully GW. Reform and efficiency gains in the New Zealand electrical supply industry. Journal of Productivity Analysis 1999; 11(2): 133-147.

[75] Shephard RW. Theory of cost and production function. Princeton: Princeton University Press; 1970.

[76] Simar L., Wilson PW. Sensitivity analysis of efficiency scores: how to bootstrap in nonparametric frontier models. Management Science 1998; 44(11): 49-61.

[77] Simar L., Wilson PW. Some problems with the Ferrier/ Hirschberg bootstrap idea. Journal of Efficiency Analysis 1999a; 11(1): 67-80.

[78] Simar L., Wilson PW. Of course we can bootstrap DEA scores! but does it mean anything? Logic trumps wishful thinking. Journal of Efficiency Analysis 1999b; 11(1): 93-97.

[79] Simar L., Wilson PW. A general methodology for bootstrapping in nonparametric frontier models. Journal of Applied Statistics 2000a; 27(6): 779-802.

[80] Simar L., Wilson PW. Statistical inference in nonparametric frontier models: the state of the art. Journal of Efficiency Analysis 2000b; 13(1): 49-78.

[81] Simar L., Wilson PW. Testing restrictions in nonparametric efficiency models. Communications in Statistics 2001a; 30(1): 159-184.

[82] Simar L., Wilson PW. Aplicaci'on del 'Bootstrap' para Estimadores D.E.A.," in La Medici'on de la Eficiencia y la Productividad, edited by A. 'Alvarez, Madrid: Pir'amide, 2001. Translation of "Performance of the Bootstrap for DEA Estimators and Iterating the Principle," Discussion Paper No. 0002, Institut de Statistique, Universit'e Catholique de Louvain, Louvaina-Neuve, Belgium. 2001b.

[83] Simar L., Wilson PW. Non-parametric tests of returns to scale. European Journal of Operational Research 2002; 139(1), 115-132. 
[84] Tone, K., Tsutsui, M. Dynamic DEA with network structure: A slacks-based measure approach. Omega 2014; 421, 124-131.

[85] Tongzon J., Heng W. Port privatization, efficiency and competitiveness: some empirical evidence from container ports (terminals), Transportation Research Part A: Policy and Practice 2005; 39(5): 405-424.

[86] Tsekouras K., Skouras D. Productive efficiency and exports: an examination of alternative hypotheses for the Greek cement industry. Applied Economics 2005; 37(3): 279-291.

[87] Tüselmann, H., Sinkovics, RR., Pishchulov, G. Towards a consolidation of worldwide journal rankings-A classification using random forests and aggregate rating via data envelopment analysis. Omega 2015; 51, 11-23.

[88] Villalonga B. Privatization and efficiency: differentiating ownership effects from political, organizational, and dynamic effects. Journal of Economic Behavior \& Organization 2000; 42(1): 43-74.

[89] Wei Z., Varela O., D’Souza J., Hassan MK. The financial and operating performance of China's newly privatised firms. Financial Management 2003; 32(2): 107-126.

[90] Wheelock DC., Wilson PW. New evidence on returns to scale and product mix among U.S. commercial banks. Journal of Monetary Economics 2001; 47(3): 653-674.

[91] Wheelock DC., and Wilson, PW. Robust non-parametric estimation of efficiency and technical change in U.S. commercial banking. Working Paper. Federal Reserve Bank of St. Louis. 2003 November.

[92] Wheelock DC., Wilson PW. Non-parametric, unconditional quantile estimation for efficiency analysis with an application to Federal Reserve check processing operations. Journal of Econometrics 2008; 45(1-2), 209-225.

[93] Wheelock DC., Wilson PW. Robust nonparametric quantile estimation of efficiency and productivity change in U.S. commercial banking, 1985-2004. Journal of Business \& Economic Statistics 2009; 27(3): 354-368.

[94] Wilson PW. FEAR: A software package for frontier efficiency analysis. Socio-Economic Planning Sciences 2008; 42(4): 247-254. 
[95] Wilson, PW., Carey K. Nonparametric analysis of returns to scale and product mix among U.S. hospitals. Journal of Applied Econometrics 2004; 19(4): 505-524.

[96] World Bank. Capacity building and modernization project of cement industry. Islamabad, Pakistan: Staff Appraisal Report; 1986.

[97] Zhang X., Zongming T., Jun H. Impact of macro and firm-specific characteristics on post privatization performance. The Chinese Economy 2012; 45(5): 50-91. 
Table 1: Summary of Empirical Studies on Change of Ownership and Firms Performance since 2000

\begin{tabular}{|c|c|c|c|c|c|}
\hline Authors & Period & Industry & Country & Method & $\begin{array}{l}\text { Post-privatization/deregulation } \\
\text { Results }\end{array}$ \\
\hline $\begin{array}{l}\text { Saal and } \\
\text { Parker [70] }\end{array}$ & $1985-99$ & $\begin{array}{l}\text { Utility: water and } \\
\text { sewerage }\end{array}$ & UK & Parametric & Productivity did not improve \\
\hline Rossi [67] & $1993-97$ & $\begin{array}{l}\text { Utility: gas } \\
\text { distribution }\end{array}$ & Argentina & Parametric & Efficiency improved \\
\hline Chirwa [25] & $1970-97$ & Manufacturing & Malawi & $\begin{array}{l}\text { Non- } \\
\text { parametric }\end{array}$ & Higher technical efficiency \\
\hline $\begin{array}{l}\text { Saygili and } \\
\text { Taymaz [73] }\end{array}$ & $1980-95$ & Manufacturing & Turkey & Parametric & No change in efficiency \\
\hline $\begin{array}{l}\text { Estache et al. } \\
\text { [38] }\end{array}$ & 1994-99 & Transport: railways & $\begin{array}{l}\text { Argentina \& } \\
\text { Brazil }\end{array}$ & $\begin{array}{l}\text { Non- } \\
\text { parametric }\end{array}$ & Improvement in productivity \\
\hline $\begin{array}{l}\text { Jones and } \\
\text { Mygind [50] }\end{array}$ & $1993-97$ & Manufacturing & Estonia & Parametric & Efficiency and productivity improved \\
\hline $\begin{array}{l}\text { Resende and } \\
\text { Faceanha [64] }\end{array}$ & $1998-99$ & $\begin{array}{l}\text { Utility: } \\
\text { telecommunication }\end{array}$ & Brazil & $\begin{array}{l}\text { Non- } \\
\text { parametric }\end{array}$ & No improvement in efficiency \\
\hline $\begin{array}{l}\text { Cullinane and } \\
\text { Song [30] }\end{array}$ & $1978-96$ & $\begin{array}{l}\text { Transport: } \\
\text { container terminal }\end{array}$ & Korea & Parametric & $\begin{array}{l}\text { Privatization improved container } \\
\text { productive efficiency }\end{array}$ \\
\hline Li and $\mathrm{Xu}[51]$ & $\begin{array}{l}1990- \\
2001\end{array}$ & $\begin{array}{l}\text { Utility: } \\
\text { telecommunication }\end{array}$ & Worldwide & Parametric & Improved total factor productivity \\
\hline Chirwa [26] & $1970-97$ & Manufacturing & Malawi & Parametric & $\begin{array}{l}\text { High technical efficiency in privatized, } \\
\text { state and private companies }\end{array}$ \\
\hline $\begin{array}{l}\text { Bartel and } \\
\text { Harrison [11] }\end{array}$ & $1981-95$ & Manufacturing & Indonesia & Parametric & $\begin{array}{l}\text { Public emperies perform worse than } \\
\text { their private-sector counterparts }\end{array}$ \\
\hline $\begin{array}{l}\text { Tongzon and } \\
\text { Heng [85] }\end{array}$ & 2004 & $\begin{array}{l}\text { Transport: } \\
\text { container ports }\end{array}$ & Worldwide & Parametric & $\begin{array}{l}\text { Private participation improved port } \\
\text { operation efficiency }\end{array}$ \\
\hline $\begin{array}{l}\text { Cullinane et } \\
\text { al.[31] }\end{array}$ & $1992-99$ & $\begin{array}{l}\text { Transport: } \\
\text { container ports }\end{array}$ & Worldwide & $\begin{array}{l}\text { Non- } \\
\text { parametric }\end{array}$ & $\begin{array}{l}\text { Private participation does not } \\
\text { improve port efficiency }\end{array}$ \\
\hline $\begin{array}{l}\text { Brown et al. } \\
{[21]}\end{array}$ & $\begin{array}{l}1994- \\
2002\end{array}$ & Manufacturing & $\begin{array}{l}\text { Romania, } \\
\text { Hungry, } \\
\text { Ukraine, } \\
\text { Russia }\end{array}$ & Parametric & $\begin{array}{l}\text { Positive effect of privatization on } \\
\text { productivity }\end{array}$ \\
\hline $\begin{array}{l}\text { Okten and } \\
\text { Arin [61] }\end{array}$ & $1983-99$ & Manufacturing & Turkey & Parametric & Improved labor productivity \\
\hline $\begin{array}{l}\text { Amess and } \\
\text { Roberts [5] }\end{array}$ & $1988-93$ & Manufacturing & Poland & Parametric & Improved productivity \\
\hline Saal et al. [71] & $\begin{array}{l}1985- \\
2000\end{array}$ & $\begin{array}{l}\text { Utility: water and } \\
\text { sewerage }\end{array}$ & $\begin{array}{l}\text { English and } \\
\text { Welsh }\end{array}$ & Parametric & No improvement in productivity \\
\hline $\begin{array}{l}\text { Asaftei et al. } \\
\text { [7] }\end{array}$ & $\begin{array}{l}1995- \\
2003\end{array}$ & Manufacturing & Romania & Parametric & $\begin{array}{l}\text { Did not perform any better than } \\
\text { public enterprise }\end{array}$ \\
\hline
\end{tabular}


Table 2: Summary Statistics for Inputs and Output

\begin{tabular}{llccccc}
\hline Variable & Scale & N & Mean & Std Dev & Minimum & Maximum \\
\hline Output & Millions Rs. & 407 & 2859.45 & 3209.53 & 16.59 & 24038.63 \\
Capital & Millions Rs. & 407 & 2535.85 & 2904.94 & 14.38 & 15140.4 \\
Labour & Number & 407 & 716.51 & 412.05 & 110 & 2550 \\
Material & Millions Rs. & 407 & 231.24 & 167.56 & 2.49 & 1142.25 \\
Fuel & Millions Rs. & 407 & 735 & 582.82 & 8.46 & 4669.1 \\
\hline
\end{tabular}

Table 3: Pakistani Cement Industry: Technical Efficiency Estimates

\begin{tabular}{|c|c|c|c|c|c|c|c|c|c|c|}
\hline Years & $\mathrm{FDH}_{\mathrm{i}}$ & $\mathrm{FDH}_{\mathrm{o}}$ & DEA $_{i}$ & $\mathrm{DEA}_{\circ}$ & $\mathrm{DEA}_{h}$ & ORDERM $_{\mathrm{i}}$ & ORDERM $_{\circ}$ & $\begin{array}{c}\alpha- \\
\text { QUANT }_{i}\end{array}$ & $\begin{array}{c}\alpha- \\
\text { QUANT。 }\end{array}$ & $\begin{array}{c}\alpha- \\
\text { QUANT }_{h}\end{array}$ \\
\hline \multicolumn{11}{|c|}{ Pre-Reforms Period } \\
\hline $1986-91$ & 1.0007 & 0.9998 & 1.0338 & 0.9676 & 1.0167 & 0.7692 & 1.4292 & 0.7096 & 0.9998 & 0.5685 \\
\hline \multicolumn{11}{|c|}{ Post-Reforms Periods } \\
\hline $1992-11$ & 1.0063 & 0.9927 & 1.0626 & 0.9351 & 1.0329 & 0.7688 & 1.2209 & 0.7947 & 1.0245 & 0.7091 \\
\hline $1992-98$ & 1.0053 & 0.9853 & 1.0889 & 0.9193 & 1.0451 & 0.7746 & 1.2961 & 0.7275 & 0.9895 & 0.6371 \\
\hline $1999-11$ & 1.0068 & 0.9967 & 1.0488 & 0.9436 & 1.0264 & 0.7658 & 1.1823 & 0.8334 & 1.0438 & 0.7512 \\
\hline 1999-06 & 1.0106 & 0.9949 & 1.0544 & 0.9396 & 1.0291 & 0.7816 & 1.1030 & 0.8523 & 1.0011 & 0.7781 \\
\hline 2007-11 & 1.0009 & 0.9996 & 1.0398 & 0.9500 & 1.0221 & 0.7411 & 1.3212 & 0.8041 & 1.1160 & 0.7101 \\
\hline
\end{tabular}


Table 4: Total Factor Productivity Estimates and its Components by Ownerships (Hyperbolic $\alpha$-quantile estimator, $\alpha=0.9$ )

\begin{tabular}{|c|c|c|c|c|c|c|c|c|c|c|c|c|}
\hline & \multicolumn{3}{|c|}{ Industrv } & \multicolumn{3}{|c|}{ Privatized-1991 } & \multicolumn{3}{|c|}{ Private } & \multicolumn{3}{|c|}{ Public } \\
\hline & $\begin{array}{c}\text { Productivity } \\
\text { change }\end{array}$ & $\begin{array}{l}\text { Efficiency } \\
\text { change }\end{array}$ & $\begin{array}{c}\text { Technical } \\
\text { change }\end{array}$ & $\begin{array}{c}\text { Productivity } \\
\text { change }\end{array}$ & $\begin{array}{l}\text { Efficiency } \\
\text { change }\end{array}$ & $\begin{array}{l}\text { Technical } \\
\text { change }\end{array}$ & $\begin{array}{c}\text { Productivity } \\
\text { change }\end{array}$ & $\begin{array}{l}\text { Efficiency } \\
\text { change }\end{array}$ & $\begin{array}{l}\text { Technical } \\
\text { change }\end{array}$ & $\begin{array}{c}\text { Productivity } \\
\text { change }\end{array}$ & $\begin{array}{c}\text { Efficiency } \\
\text { change }\end{array}$ & $\begin{array}{c}\text { Technical } \\
\text { change }\end{array}$ \\
\hline 1987 & 1.072 & 1.049 & 1.023 & 1.181 & 1.275 & 0.926 & 1.180 & 0.985 & 1.198 & 1.054 & 1.061 & 0.994 \\
\hline 1988 & 0.955 & 0.958 & 0.997 & 0.935 & 0.942 & 0.992 & 0.990 & 1.004 & 0.986 & 0.946 & 0.946 & 1.000 \\
\hline 1989 & 1.029 & 1.025 & 1.004 & 1.043 & 1.010 & 1.033 & 1.019 & 1.024 & 0.995 & 1.032 & 1.025 & 1.006 \\
\hline 1990 & 1.046 & 1.031 & 1.015 & 1.007 & 0.988 & 1.020 & 1.262 & 1.266 & 0.997 & 0.994 & 0.975 & 1.020 \\
\hline 1991 & 1.002 & 0.969 & 1.035 & 1.014 & 0.991 & 1.023 & 1.064 & 0.927 & 1.148 & 0.986 & 0.980 & 1.006 \\
\hline 1992 & 0.979 & 1.016 & 0.963 & 1.070 & 1.127 & 0.950 & 0.897 & 0.922 & 0.972 & 0.921 & 0.947 & 0.973 \\
\hline 1993 & 1.017 & 1.035 & 0.982 & 1.037 & 1.069 & 0.970 & 1.110 & 1.122 & 0.989 & 0.911 & 0.945 & 0.965 \\
\hline 1994 & 0.978 & 1.025 & 0.954 & 1.032 & 1.035 & 0.998 & 0.970 & 1.061 & 0.914 & 0.894 & 0.995 & 0.898 \\
\hline 1995 & 1.018 & 0.972 & 1.048 & 1.020 & 0.971 & 1.051 & 0.918 & 0.961 & 0.955 & 1.137 & 0.956 & 1.190 \\
\hline 1996 & 0.998 & 0.949 & 1.052 & 1.031 & 0.998 & 1.034 & 1.092 & 0.850 & 1.286 & 0.852 & 0.941 & 0.906 \\
\hline 1997 & 1.009 & 1.011 & 0.998 & 1.043 & 0.993 & 1.051 & 1.028 & 1.039 & 0.989 & 0.918 & 0.991 & 0.927 \\
\hline 1998 & 0.991 & 1.002 & 0.989 & 1.044 & 1.082 & 0.965 & 1.015 & 1.001 & 1.014 & 0.923 & 0.946 & 0.975 \\
\hline 1999 & 0.939 & 1.000 & 0.939 & 0.922 & 1.099 & 0.839 & 0.968 & 0.974 & 0.995 & 1.010 & 1.016 & 0.994 \\
\hline 2000 & 0.982 & 1.045 & 0.940 & 0.911 & 0.991 & 0.919 & 1.029 & 1.080 & 0.953 & 0.837 & 0.923 & 0.907 \\
\hline 2001 & 0.970 & 0.984 & 0.986 & 0.930 & 0.894 & 1.041 & 1.032 & 1.055 & 0.978 & 0.774 & 0.901 & 0.860 \\
\hline 2002 & 0.989 & 1.047 & 0.945 & 1.006 & 1.073 & 0.938 & 0.961 & 1.007 & 0.955 & 1.054 & 1.200 & 0.879 \\
\hline 2003 & 0.940 & 0.947 & 0.993 & 1.029 & 1.053 & 0.978 & 0.947 & 0.923 & 1.026 & & & \\
\hline 2004 & 0.976 & 1.034 & 0.944 & 1.035 & 1.076 & 0.962 & 0.937 & 1.009 & 0.928 & & & \\
\hline 2005 & 1.033 & 0.974 & 1.061 & 1.020 & 0.957 & 1.065 & 1.035 & 0.962 & 1.076 & & & \\
\hline 2006 & 0.996 & 0.954 & 1.044 & 0.986 & 0.952 & 1.035 & 1.006 & 1.002 & 1.004 & & & \\
\hline 2007 & 1.146 & 1.064 & 1.077 & 1.006 & 0.976 & 1.031 & 1.070 & 0.943 & 1.135 & & & \\
\hline 2008 & 0.870 & 1.005 & 0.866 & 0.884 & 1.061 & 0.833 & 0.840 & 0.934 & 0.899 & & & \\
\hline 2009 & 0.944 & 0.937 & 1.007 & 0.934 & 0.928 & 1.006 & 0.943 & 0.969 & 0.973 & & & \\
\hline 2010 & 0.935 & 0.893 & 1.047 & 0.847 & 0.790 & 1.071 & 1.033 & 1.010 & 1.023 & & & \\
\hline 2011 & 0.905 & 1.030 & 0.878 & 0.931 & 1.057 & 0.881 & 0.925 & 1.072 & 0.862 & & & \\
\hline 1986-1991 & 1.020 & 1.006 & 1.014 & 1.033 & 1.035 & 0.998 & 1.098 & 1.035 & 1.061 & 1.002 & 0.997 & 1.005 \\
\hline $1992-2011$ & 0.979 & 0.995 & 0.984 & 0.984 & 1.006 & 0.978 & 0.986 & 0.993 & 0.993 & 0.925 & 0.975 & 0.949 \\
\hline $1992-2011^{\mathrm{a}}$ & 0.971 & 0.992 & 0.979 & 0.983 & 1.007 & 0.976 & 0.981 & 0.996 & 0.986 & & & \\
\hline $1992-1998$ & 0.998 & 1.001 & 0.997 & 1.040 & 1.038 & 1.002 & 1.002 & 0.990 & 1.011 & 0.933 & 0.960 & 0.972 \\
\hline $1999-2011^{\mathrm{a}}$ & 0.956 & 0.986 & 0.969 & 0.951 & 0.990 & 0.961 & 0.970 & 0.999 & 0.971 & & & \\
\hline
\end{tabular}

Notes: a. excluding 2007. 
Table 5: Pearson Correlation Coefficients

\begin{tabular}{|c|c|c|c|c|c|c|c|c|c|c|c|c|c|c|}
\hline & malm & old & export & hhi_grsa & gdp & manufac & gfcf & pubinv & devexp & pop & exchr & remit & post92 & politics \\
\hline malm & 1.000 & & & & & & & & & & & & & \\
\hline old & -0.043 & 1.000 & & & & & & & & & & & & \\
\hline export & -0.036 & 0.059 & 1.000 & & & & & & & & & & & \\
\hline hhi_grsa & 0.002 & 0.190 & 0.466 & 1.000 & & & & & & & & & & \\
\hline gdp & -0.072 & 0.333 & 0.525 & 0.736 & 1.000 & & & & & & & & & \\
\hline manufac & -0.027 & 0.353 & 0.456 & 0.647 & 0.922 & 1.000 & & & & & & & & \\
\hline gfcf & -0.040 & 0.345 & 0.501 & 0.721 & 0.956 & 0.982 & 1.000 & & & & & & & \\
\hline pubinv & -0.053 & 0.338 & 0.526 & 0.766 & 0.974 & 0.947 & 0.983 & 1.000 & & & & & & \\
\hline devexp & -0.028 & 0.332 & 0.516 & 0.783 & 0.951 & 0.959 & 0.986 & 0.980 & 1.000 & & & & & \\
\hline pop & -0.065 & 0.363 & 0.406 & 0.448 & 0.888 & 0.930 & 0.906 & 0.889 & 0.851 & 1.000 & & & & \\
\hline exchr & -0.090 & 0.348 & 0.435 & 0.472 & 0.912 & 0.893 & 0.896 & 0.897 & 0.839 & 0.978 & 1.000 & & & \\
\hline remit & -0.049 & 0.308 & 0.530 & 0.807 & 0.947 & 0.890 & 0.925 & 0.924 & 0.943 & 0.776 & 0.791 & 1.000 & & \\
\hline post92 & -0.056 & 0.246 & 0.144 & -0.036 & 0.430 & 0.509 & 0.454 & 0.467 & 0.393 & 0.699 & 0.637 & 0.248 & 1.000 & \\
\hline politics & -0.052 & 0.188 & 0.108 & -0.016 & 0.415 & 0.492 & 0.403 & 0.312 & 0.352 & 0.509 & 0.476 & 0.410 & 0.315 & 1.000 \\
\hline
\end{tabular}

Notes: Variables explanation

malm : Malmquist productivity index

old : Firm age (in years)

export : Export sale (in millions Pak Rupees (Rs.))

hhi grsa : Herfindhal Index (a proxy for competition based on gross sales of each firm)

gdp : Volume of gross domestic product (Rs. billions)

manufac : Manufacturing production index (base $=100$ )

gfcf : Gross fixed capital formation (Pak. Rs. Millions)

pubinv : Public investment (Pak. Rs. Millions)

devexp : Government development expenditure (Pak. Rs. Millions)

pop : Population (Millions)

exchr : Exchange rate (Pak. Rs./\$)

remit : Foreign remittances (millions US\$)

post92 : Dummy variable $=1$ for post privatisation/deregulation period (1992 onward), 0 otherwise

politics : Political stability variable calculated as number of years a government was in power. More means political stability 
Figure 1: Structure of the Cement Industry

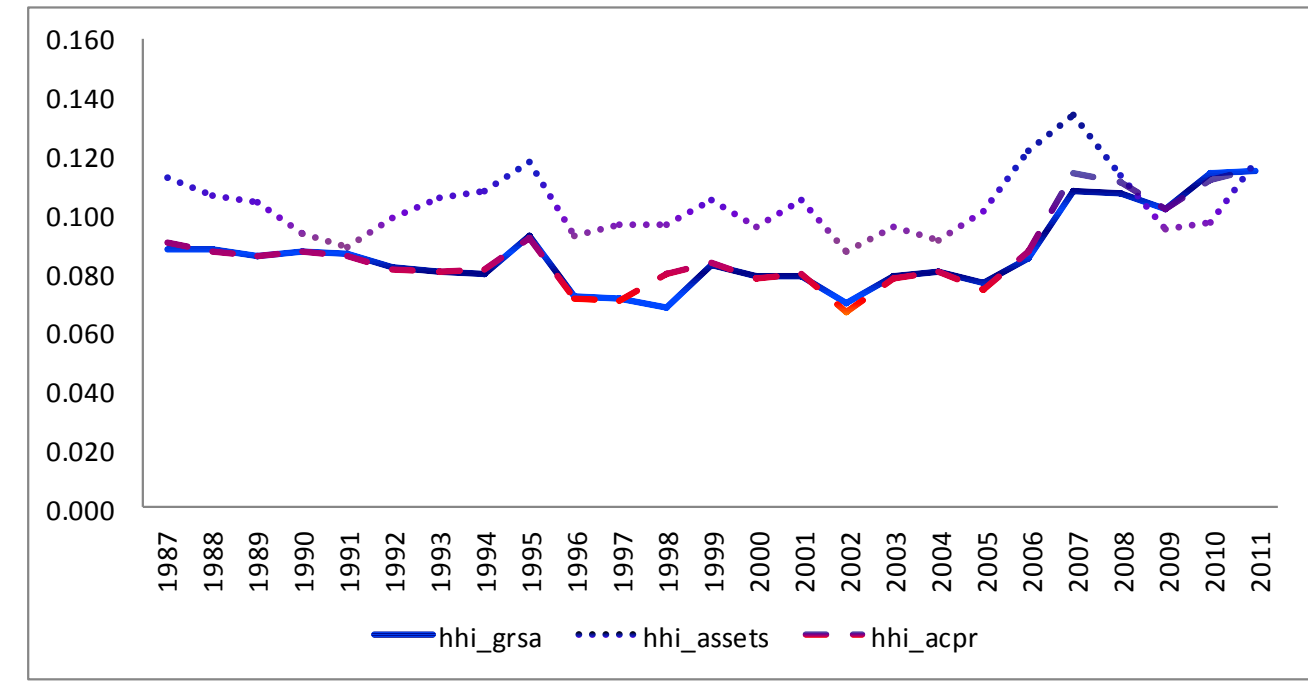

Notes:

hhi_grsa : Total gross sales Herfindhal Index

hhi_assets: Total assets Herfindhal Index

hhi_acpr: Actual production capacity Herfindhal Index

Figure 2: Unconditional Hyperbolic $\alpha$-Quantile Efficiency Estimates and Variance

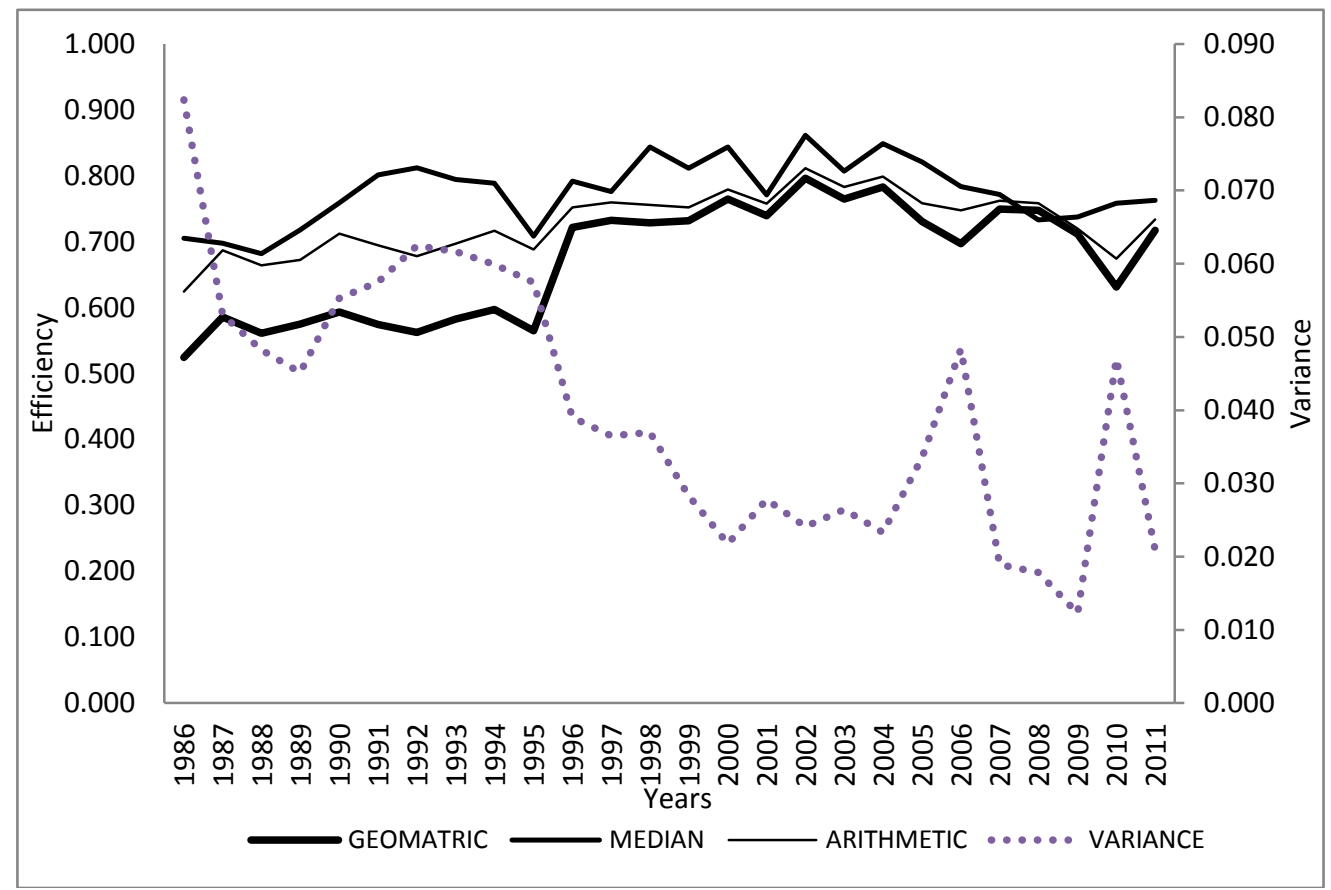


Figure 3: Unconditional Hyperbolic $\alpha$-Quantile Efficiency Estimates by Ownerships

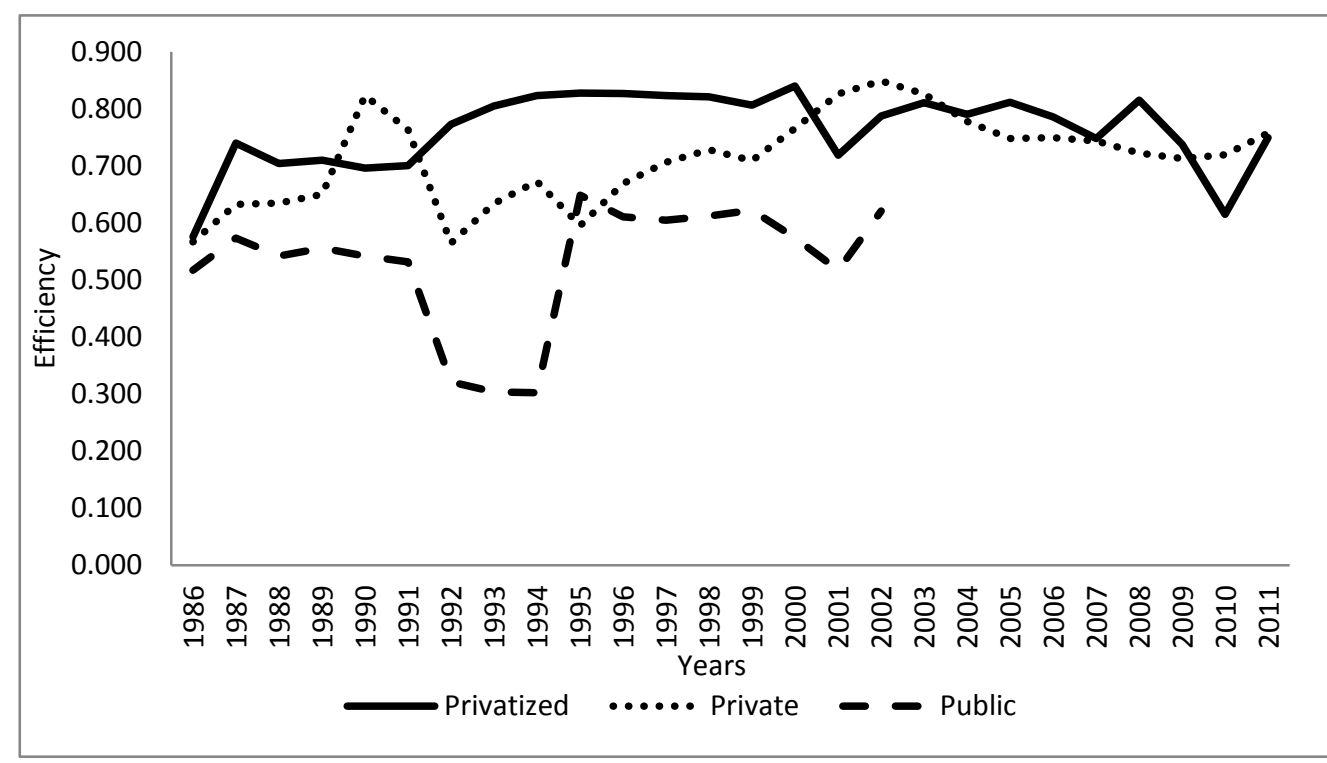


Appendix-A Sensitivity of Technical Efficiency Estimates

\begin{tabular}{lccccc}
\hline & $\alpha$-QUANT & $\alpha$-QUANT & $\alpha$-QUANT & ORDERM $_{\mathrm{i}}$ & ORDERM $_{\mathrm{o}}$ \\
\hline Period & $\alpha=0.80$ & $\alpha=0.85$ & $\alpha=0.87$ & $\mathrm{~m}=4$ & $\mathrm{~m}=4$ \\
1986 & 0.413 & 0.525 & 0.525 & 0.692 & 1.612 \\
1987 & 0.518 & 0.518 & 0.586 & 0.720 & 1.779 \\
1988 & 0.506 & 0.506 & 0.561 & 0.709 & 1.832 \\
1989 & 0.520 & 0.520 & 0.575 & 0.716 & 1.840 \\
1990 & 0.513 & 0.513 & 0.593 & 0.737 & 1.903 \\
1991 & 0.512 & 0.512 & 0.575 & 0.754 & 2.110 \\
1992 & 0.454 & 0.503 & 0.563 & 0.720 & 2.495 \\
1993 & 0.477 & 0.525 & 0.582 & 0.730 & 1.714 \\
1994 & 0.511 & 0.554 & 0.597 & 0.735 & 1.834 \\
1995 & 0.499 & 0.499 & 0.565 & 0.720 & 1.942 \\
1996 & 0.619 & 0.648 & 0.648 & 0.757 & 1.123 \\
1997 & 0.594 & 0.632 & 0.632 & 0.755 & 1.142 \\
1998 & 0.573 & 0.624 & 0.624 & 0.741 & 1.204 \\
1999 & 0.589 & 0.631 & 0.631 & 0.735 & 1.206 \\
2000 & 0.626 & 0.673 & 0.673 & 0.738 & 1.144 \\
2001 & 0.618 & 0.666 & 0.666 & 0.728 & 1.124 \\
2002 & 0.628 & 0.709 & 0.709 & 0.748 & 1.106 \\
2003 & 0.584 & 0.681 & 0.681 & 0.721 & 1.128 \\
2004 & 0.639 & 0.683 & 0.683 & 0.769 & 1.116 \\
2005 & 0.579 & 0.656 & 0.656 & 0.741 & 1.136 \\
2006 & 0.560 & 0.620 & 0.620 & 0.732 & 1.172 \\
2007 & 0.525 & 0.612 & 0.612 & 0.712 & 1.417 \\
2008 & 0.542 & 0.597 & 0.597 & 0.697 & 1.527 \\
2009 & 0.517 & 0.592 & 0.592 & 0.677 & 1.426 \\
2010 & 0.474 & 0.534 & 0.534 & 0.665 & 1.482 \\
2011 & 0.609 & 0.609 & 0.717 & 0.743 & 1.296 \\
\hline $1986-91$ & 0.496 & 0.516 & 0.569 & 0.721 & 1.840 \\
$1992-11$ & 0.558 & 0.609 & 0.627 & 0.728 & 1.349 \\
$1992-98$ & 0.529 & 0.566 & 0.601 & 0.737 & 1.570 \\
$1999-11$ & 0.574 & 0.634 & 0.642 & 0.723 & 1.244 \\
$1999-06$ & 0.602 & 0.664 & 0.664 & 0.739 & 1.141 \\
$2007-11$ & 0.532 & 0.588 & 0.608 & 0.698 & 1.428 \\
\hline & & & & &
\end{tabular}


Appendix B Sensitivity of Total Factor Productivity Estimates and its Components by Ownerships $(\alpha=0.8)$

\begin{tabular}{|c|c|c|c|c|c|c|c|c|c|c|c|c|}
\hline & \multicolumn{3}{|c|}{ Industrv } & \multicolumn{3}{|c|}{ Privatized-1991 } & \multicolumn{3}{|c|}{ Private } & \multicolumn{3}{|c|}{ Public } \\
\hline 1987 & $\begin{array}{c}\text { Productivity } \\
1.141\end{array}$ & $\begin{array}{c}\text { Efficiency } \\
1.151\end{array}$ & $\begin{array}{c}\text { Technical } \\
0.991\end{array}$ & $\begin{array}{c}\text { Productivity } \\
1.229\end{array}$ & $\begin{array}{c}\text { Efficiency } \\
1.305\end{array}$ & $\begin{array}{c}\text { Technical } \\
0.942\end{array}$ & $\begin{array}{c}\text { Productivity } \\
1.436\end{array}$ & $\begin{array}{c}\text { Efficiency } \\
1.236\end{array}$ & $\begin{array}{c}\text { Technical } \\
1.162\end{array}$ & $\begin{array}{c}\text { Productivity } \\
1.094\end{array}$ & $\begin{array}{c}\text { Efficiency } \\
1.136\end{array}$ & $\begin{array}{c}\text { Technical } \\
0.963\end{array}$ \\
\hline 1988 & 0.960 & 0.976 & 0.984 & 0.937 & 0.969 & 0.967 & 1.021 & 1.007 & 1.014 & 0.944 & 0.967 & 0.975 \\
\hline 1989 & 1.021 & 1.028 & 0.993 & 1.045 & 1.041 & 1.004 & 1.019 & 1.043 & 0.977 & 1.022 & 1.024 & 0.998 \\
\hline 1990 & 1.052 & 0.987 & 1.066 & 1.004 & 0.936 & 1.074 & 1.250 & 1.123 & 1.114 & 1.004 & 0.953 & 1.054 \\
\hline 1991 & 1.006 & 0.997 & 1.009 & 0.986 & 0.993 & 0.992 & 1.097 & 1.067 & 1.028 & 0.982 & 0.978 & 1.004 \\
\hline 1992 & 0.980 & 1.021 & 0.960 & 1.066 & 1.106 & 0.964 & 0.906 & 0.950 & 0.954 & 0.928 & 0.948 & 0.979 \\
\hline 1993 & 1.027 & 1.051 & 0.977 & 1.038 & 1.075 & 0.965 & 1.097 & 1.121 & 0.979 & 0.964 & 0.973 & 0.990 \\
\hline 1994 & 1.008 & 1.071 & 0.941 & 1.096 & 1.135 & 0.965 & 1.015 & 1.025 & 0.990 & 0.893 & 1.077 & 0.829 \\
\hline 1995 & 0.999 & 0.930 & 1.074 & 0.986 & 0.879 & 1.121 & 0.929 & 0.996 & 0.932 & 1.142 & 0.943 & 1.212 \\
\hline 1996 & 0.996 & 0.966 & 1.032 & 1.053 & 1.062 & 0.991 & 1.070 & 0.871 & 1.228 & 0.832 & 0.877 & 0.948 \\
\hline 1997 & 0.972 & 0.985 & 0.987 & 0.964 & 0.971 & 0.993 & 0.982 & 0.952 & 1.032 & 0.960 & 1.034 & 0.928 \\
\hline 1998 & 1.000 & 0.966 & 1.036 & 0.998 & 0.971 & 1.028 & 1.056 & 1.023 & 1.033 & 0.894 & 0.842 & 1.062 \\
\hline 1999 & 0.953 & 1.022 & 0.933 & 0.911 & 1.064 & 0.857 & 1.025 & 1.034 & 0.992 & 1.019 & 1.098 & 0.928 \\
\hline 2000 & 0.979 & 1.064 & 0.920 & 0.865 & 0.984 & 0.879 & 1.038 & 1.133 & 0.916 & 0.902 & 0.926 & 0.974 \\
\hline 2001 & 0.953 & 0.959 & 0.993 & 1.010 & 0.998 & 1.012 & 0.986 & 0.943 & 1.046 & 0.770 & 0.984 & 0.782 \\
\hline 2002 & 0.976 & 0.980 & 0.996 & 0.931 & 0.914 & 1.019 & 0.993 & 1.076 & 0.923 & 1.001 & 0.760 & 1.317 \\
\hline 2003 & 0.929 & 0.926 & 1.004 & 0.979 & 0.982 & 0.997 & 0.936 & 0.907 & 1.032 & & & \\
\hline 2004 & 0.963 & 1.012 & 0.952 & 1.067 & 1.121 & 0.952 & 0.899 & 0.940 & 0.957 & & & \\
\hline 2005 & 0.979 & 0.945 & 1.036 & 0.968 & 0.867 & 1.115 & 0.984 & 0.987 & 0.997 & & & \\
\hline 2006 & 0.978 & 0.968 & 1.011 & 0.992 & 0.997 & 0.995 & 0.964 & 0.937 & 1.028 & & & \\
\hline 2007 & 1.074 & 0.919 & 1.169 & 0.947 & 0.833 & 1.138 & 1.009 & 0.849 & 1.189 & & & \\
\hline 2008 & 0.867 & 1.014 & 0.854 & 0.881 & 0.993 & 0.888 & 0.846 & 1.006 & 0.841 & & & \\
\hline 2009 & 0.982 & 0.927 & 1.059 & 1.068 & 0.870 & 1.228 & 0.967 & 0.961 & 1.006 & & & \\
\hline 2010 & 0.938 & 0.922 & 1.017 & 0.929 & 0.920 & 1.009 & 0.991 & 1.000 & 0.991 & & & \\
\hline 2011 & 0.918 & 1.052 & 0.873 & 0.956 & 1.069 & 0.895 & 0.919 & 1.059 & 0.868 & & & \\
\hline 1986-1991 & 1.034 & 1.026 & 1.008 & 1.036 & 1.041 & 0.995 & 1.154 & 1.092 & 1.057 & 1.008 & 1.010 & 0.998 \\
\hline $1992-2011$ & 0.973 & 0.984 & 0.989 & 0.983 & 0.987 & 0.997 & 0.979 & 0.986 & 0.993 & 0.932 & 0.946 & 0.985 \\
\hline $1992-2011^{a}$ & 0.968 & 0.987 & 0.980 & 0.985 & 0.996 & 0.990 & 0.977 & 0.994 & 0.984 & & & \\
\hline $1992-1998$ & 0.998 & 0.997 & 1.000 & 1.028 & 1.025 & 1.003 & 1.006 & 0.988 & 1.017 & 0.941 & 0.953 & 0.987 \\
\hline $1999-2011^{\mathrm{a}}$ & 0.951 & 0.981 & 0.969 & 0.961 & 0.979 & 0.982 & 0.961 & 0.997 & 0.964 & & & \\
\hline
\end{tabular}

Notes: a. excluding 2007 